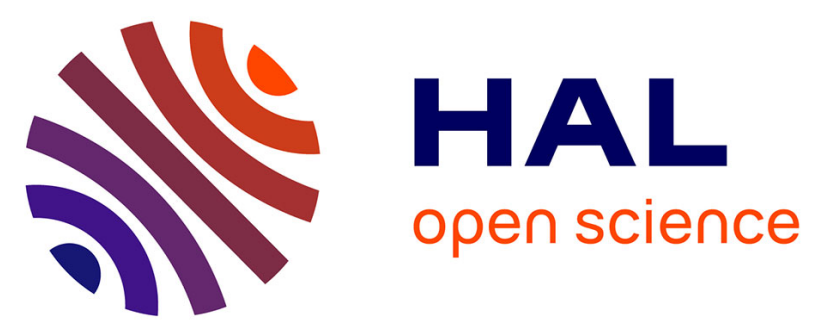

\title{
From crustal anatexis to mantle melting in the Variscan orogen of Corsica (France): SIMS U-Pb zircon age constraints
}

Xian-Hua Li, Michel Faure, Wei Lin

\section{- To cite this version:}

Xian-Hua Li, Michel Faure, Wei Lin. From crustal anatexis to mantle melting in the Variscan orogen of Corsica (France): SIMS U-Pb zircon age constraints. Tectonophysics, 2014, 634, pp.19-30. 10.1016/j.tecto.2014.07.021 . insu-01056700

\section{HAL Id: insu-01056700 \\ https://hal-insu.archives-ouvertes.fr/insu-01056700}

Submitted on 21 Aug 2014

HAL is a multi-disciplinary open access archive for the deposit and dissemination of scientific research documents, whether they are published or not. The documents may come from teaching and research institutions in France or abroad, or from public or private research centers.
L'archive ouverte pluridisciplinaire HAL, est destinée au dépôt et à la diffusion de documents scientifiques de niveau recherche, publiés ou non, émanant des établissements d'enseignement et de recherche français ou étrangers, des laboratoires publics ou privés. 


\title{
From crustal anatexis to mantle melting in the Variscan orogen of Corsica (France): SIMS U-Pb zircon age constraints
}

\author{
Xian-Hua Li ${ }^{1} *, \quad$ Michel Faure ${ }^{2}, \quad$ Wei Lin ${ }^{1}$
}

1. State Key Laboratory of Lithospheric Evolution, Institute of Geology and Geophysics, Chinese Academy of Sciences, Beijing 100029, China

2. Institut des Sciences de la Terre d'Orléans, Université d'Orléans, 45067 Orléans Cedex 2, France

*Corresponding author

E-mail: lixh@gig.ac.cn

Phone: 86-10-82998512

Fax: 86-10-62010846 


\section{ABSTRACT}

High-precision SIMS U-Pb zircon age determinations are conducted in this study on the migmatites and the $\mathrm{Mg}-\mathrm{K}$ magmatic rock suites from the Variscan orogen of Corsica (France). Zircons from leucosomes of four migmatites yield consistent crystallization ages of ca. $345 \mathrm{Ma}$. Four Mg-K granitoid rocks and one monzogabbro enclave from the Calvi-Ile Rousse pluton of NW Corsica yield indistinguishable U-Pb zircon ages of ca. $330 \mathrm{Ma}$. These new SIMS zircon $\mathrm{U}-\mathrm{Pb}$ dating results indicate that the regional migmatization under amphibolite-facies condition occurred synchronously at ca. 345 Ma throughout the Corsican Variscan chain. There is a ca. 15 m.y. time interval between anatexis of the thickened crust and partial melting of the metasomatized mantle and overlying crust to form the $\mathrm{Mg}-\mathrm{K}$ rock suites. We acknowledge three major discrete tectonothermal events at ca. $360 \mathrm{Ma}$, ca. $345 \mathrm{Ma}$, and ca. $330 \mathrm{Ma}$. The widespread distribution of migmatites at ca. $345 \mathrm{Ma}$ and the Mg-K magmatism at ca. $330 \mathrm{Ma}$, whatever the tectonic domains, are attributed to a single post-collisional event. The heat supply necessary to trigger crustal melting is considered as due to an asthenospheric process. Though several possibilities can be considered, we argue for a kind of slab break-off model. A tearing, or a roll-back, of the subducting lithospheric slab would initiate the asthenospheric rise able to provide the high heat input necessary for melting of the overlying continental crust at ca. $345 \mathrm{Ma}$. The final break-off of the subducting slab would enhance the rise of hot asthenosphere and metasomatism of continental 
lithosphere leading to $\mathrm{Mg}-\mathrm{K}$ mafic-granitoid magmatism at ca. $330 \mathrm{Ma}$.

Keywords: Migmatite, granite, SIMS U-Pb zircon age, Variscan orogen, slab break-off, Corsica 


\section{Introduction}

Continental collision initiates with the subduction of the continental passive margin, and proceeds to crustal thickening, then to late- and post-orogenic collapse. High-grade metamorphism and magmatism often take place after the collision. The origin of heat necessary to trigger these high temperature events is still disputed. Fluid circulation that may enhance melting of pelitic sediments and ancient felsic magmatic rocks (i.e. orthogneiss) involved in thickening of the crust was initially proposed for the Himalayas (e.g., Le Fort, 1975; Le Fort et al., 1987). However, break-off of the subducting lithospheric slab and/or convective removal (i.e. delamination) of mantle lithosphere are also proposed mechanisms (e.g. Davies and von Blanckenburg, 1995; Elkins-Tanton, 2005). The timing and duration of metamorphism and syn- to post-collisional magmatism are fundamental parameters to understand the evolution of collisional orogeny.

The Variscan belt experienced a long and complex history during which partially molten crust is widespread. In France, a polyorogenic evolution has been documented on the basis of structural and geochronological studies in the Massif Central and Massif Armoricain areas (e.g. Faure et al., 2005; Ballèvre et al., 2009). There, Devonian and Carboniferous episodes of crustal melting, giving rise to migmatites and granitoids are well acknowledged. The Variscan orogenic segment of Corsica preserves complete records of eclogite- to amphibolite-facies metamorphism. Furthermore crustal anatexis and a full 
spectrum of syn- to post-collisional magmatic rocks are well developed there, providing one of the excellent natural laboratories to study the geodynamic evolution of metamorphism and magmatism at different stages of a collisional orogen. In the past decades several geochronological investigations were conducted on various rock types in the Corsican Variscan orogen (e.g., Paquette et al., 2003; Rossi et al., 1995, 2009; Cocherie et al., 2005; Renna et al., 2007; Giacommini et al., 2008). While a general geochronological framework for the metamorphism and magmatism during the orogenic evolution, similar to other segments of the Variscan Belt, has been established (see Rossi et al. 2009, for the most recent synthesis), some rock types such as migmatites are yet to be precisely dated.

The aim of this study is to provide precise SIMS U-Pb zircon dating of migmatites formed under amphibolite-facies metamorphic conditions and $\mathrm{Mg}-\mathrm{K}$ suite intrusions, in order to place robust geochronological constraints on time interval between crustal anatexis and mantle melting, then to discuss the possible geodynamic mechanisms that might account for this evolution.

\section{Geological background and sample descriptions}

Together with Sardinia, Corsica is a part of the European Variscan belt that was connected with other segments exposed in continental Europe before the Oligocene-Miocene opening of the Algéro-Provençal and Tyrrhenian marine basins to the West and East of the islands, respectively (Edel et al., 1981). 
Corsica consists of two major tectonic domains (e.g. Durand-Delga and Rossi, 1991, Rossi et al., 2009): Alpine Corsica to the northeast, and Crystalline Corsica occupying the rest of the island (Fig. 1). The Alpine Corsica is a Paleogene high-pressure, low-temperature metamorphic nappe pile, consisting largely of Mesozoic ocean-derived sequences emplaced during the Alpine orogeny. The Crystalline Corsica, also known as the Variscan Corsica or Corsican batholith, consists of abundant syn- to late-orogenic granitoids, rare Variscan metamorphic septa, and pieces of pre-Variscan basement (e.g., Ménot and Orsini, 1990; Durand-Delga and Rossi, 1991; Lardeaux et al., 1994). The Variscan metamorphic septa, sporadically present as relics within the granitoid batholith, include the Solenzara-Fautea and Porto Vecchio septa in southeastern Corsica, the Zicavo septum in central Corsica, the Vignola septum in southwestern Corsica, the Topiti septum north of Ajaccio, and the Belgodère septum in northern Corsica. Moreover, Neoproterozoic metamorphic and magmatic rocks unconformably covered by unmetamorphozed Paleozoic sedimentary rocks represent a pre-Variscan basement (Durand-Delga and Rossi, 1991; Rossi et al., 1995, 2009; Fig. 1). The main exposures form the Argentella septum, south of Calvi, and the Agriates-Tenda "brown rocks" that develop from the north of the Tenda pluton up to Corte. These latter formations are commonly highly weathered hornfelses formed during the emplacement of the Carboniferous Tenda granite and overprinted by Alpine brittle deformation.

The Solenzara-Fautea septum consists mainly of metatexites enclosing 
restites of mafic and felsic magmatic rocks, and marble (Fig. 1, Libourel, 1985, Rouire et al., 1993, Giacomini et al., 2008). High-pressure felsic granulites with garnet-kyanite-K-feldspar-plagioclase crop out in the southern part of this complex. Eclogite and plagioclase-garnet pyroxenite retrogressed in garnet amphibolites are found as restites within the migmatite.

The Belgodère septum is the largest one in Variscan Corsica (Fig. 1). The dominant lithology is represented by migmatite with $\mathrm{m}$ - to $\mathrm{km}$-sized restites. In the eastern part of the complex, alternations of felsic-mafic rocks known as "leptynite-amphibolite series", and micaschist are well exposed. In the less deformed amphibolites, gabbroic magmatic textures are still preserved. Furthermore, garnet amphibolite containing plagioclase-symplectite developed around garnet argues for relict eclogites (Palagi et al., 1985). Metaconglomerate and paragneiss crop out in the southern part of the septum. The foliation attitude of the Belgodère septum reveals an antiformal structure overturned to the East. Fold vergence, and other kinematic indicators are consistent with a top-to-the-east sense of shear.

The Vignola septum is the smallest one that crops out at the western termination of the Ajaccio gulf. It consists of biotite-muscovite metatexite with 10 to $50 \mathrm{~cm}$-sized mafic restites. The small surface of outcrop does not allow us to provide the geometry of this septum.

Since the Porto Vecchio, Zicavo, and Topiti septa have not been studied in this study, their detail lithology and structure are not given here. For recent 
additional structural information the reader is referred to Faure et al. (2014 in review). In summary, in spite of quite similar protoliths, the Variscan metamorphic septa can be subdivided in two groups on the basis of their km-scale structure, polyphase deformation, and related kinematics. The eastern domain, exposed in the Belgodère migmatites with restitic high-pressure relics, is characterized by top-to-the-east shearing above an eastern basement represented by the Agriates-Tenda "brown rocks". Other septa, namely the Solenzara-Fautea, Porto Vecchio, Zicavo, Vignola, and Topiti, form a western domain characterized by a polyphase and polymetamorphic evolution, from eclogite, granulite, and amphibolite facies conditions. In these areas, the first tectonic-metamorphic event, with top-to-the-SW ductile shearing, corresponds to crustal thickening, and the second one, with top-to-the-SE ductile shearing, represents the subsequent thinning stage and exhumation of the amphibolite facies rocks (Faure et al., 2014 in review).

The granitoid rocks making up the Corsica batholith are grouped into three main suites (U1 to U3). The earliest U1 intrusions dated at ca. 350-320 Ma (e.g. Rossi et al., 1988; Cocherie et al., 1992, 1994; Rossi and Cocherie, 1995; Paquette et al. 2003) are exposed in western and northwestern Corsica. They consist mostly of quartz monzonites and monzogranites associated with comagmatic, ultra-potassic mafic stocks and enclaves ranging in size from a few cm to 1 km (e.g., Orsini et al. 1991; Cocherie et al. 1994; Ferré and Leake 2001; Paquette et al. 2003). The U1 suites, characterized by abundance of 
K-feldspar megacrysts and presence of macroscopic sphene, are referred to as Mg-K granitoids due to their high Mg and K contents (e.g. Cocherie et al., 1992; Ferré and Leake 2001). These intrusions form generally steeply dipping, NS-trending sheets, with a magmatic foliation conformable to the foliation in the gneissic country rocks at map scale (Laporte, 1987). Following the U1 magmatic event was the widespread U2 suite of low-K calc-alkaline granites and volcanic rocks as well as minor mafic intrusions dated at ca. 320-305 Ma (Cocherie, 1984; Rossi et al., 1993; Cocherie et al. 1994; Paquette et al. 2003). The U2 granites form the main part of the Corsica batholith, consisting mainly of amphibole-biotite granodiorite, biotite-monzogranite and leucomonzogranite. The U3 suite of alkaline plutonic and volcanic rocks, emplaced as ring plutons and lava flows dated at ca. $290-280 \mathrm{Ma}$, marks the end of the regional magmatic activity (Cocherie et al., 1984; Rossi et al., 1993; Poitrasson; et al. 1994, 1995, 1998; Paquette et al. 2003; Cocherie et al. 2005; Renna et al. 2007). The U3 rocks are exposed in calderas eroded at different levels, from plutonic roots to volcanic formations.

On the basis of field and petrographic investigations, we selected four migmatite samples and one gneissic granodiorite sample from the Variscan metamorphic septa, and five U1 Mg-K intrusive rocks for SIMS U-Pb zircon geochronological study. Sample $11 \mathrm{CO} 21\left(41^{\circ} 44^{\prime} 02.2^{\prime \prime} \mathrm{N}, 9^{\circ} 24^{\prime} 09.8^{\prime \prime} \mathrm{E}\right)$ is a leucosome within the stromatic migmatite from the Solenzara-Fautea metamorphic septum in southeastern Corsica. The migmatite is intercalated 
with amphibolite-felsic gneisses sequences. The leucosome consists of ca. $40 \%$ quartz, ca. $35 \%$ K-feldspar, ca. $10 \%$ plagioclase, ca. $12 \%$ garnet, ca. $3 \%$ sillimanite and minor amount of biotite and muscovite as well as accessory minerals. Two leucosome samples, 11CO94A and 11C094C $\left(41^{\circ} 55^{\prime} 02.3^{\prime \prime} \mathrm{N}\right.$, $8^{\circ} 38^{\prime} 30.1$ 'E) were collected from the migmatite within the Vignola metamorphic septum to the west of Ajaccio in western Corsica. Both leucosomes are granitic in composition. Sample 11C094A consists of ca. $40 \%$ plagioclase, ca. $35 \%$ K-feldspar, ca. $20 \%$ quartz and ca. $3 \%$ biotite, whereas sample $11 \mathrm{CO} 94 \mathrm{C}$ is composed of ca. $50 \%$ plagioclase, ca. $15 \%$ K-feldspar, ca. $20 \%$ quartz, ca. $15 \%$ biotite and accessory minerals. In the Belgodère metamorphic septum to the north of Corsica, migmatite is highly enriched in banded leucosomes. One leucosome sample $11 \mathrm{CO} 67\left(42^{\circ} 34^{\prime} 12.6^{\prime \prime} \mathrm{N}, 9^{\circ} 00^{\prime} 59.0^{\prime \prime} \mathrm{E}\right)$ consists of ca. $65 \%$ plagioclase, ca. $15 \% \mathrm{~K}$-feldspar, ca. $15 \%$ quartz, ca. $3 \%$ biotite as well as accessory minerals. A magmatically foliated granodiorite sample 11C066 $\left(42^{\circ} 34^{\prime} 16.2^{\prime \prime} \mathrm{N}, 9^{\circ} 00^{\prime} 56.5^{\prime \prime} \mathrm{E}\right)$ that intruded into the migmatite was also collected. It consists of ca. $50 \%$ plagioclase, ca. $25 \%$ K-feldspar, ca. 20 quartz and ca. $5 \%$ biotite.

Five samples were collected from the Calvi-lle Rousse pluton of the U1 suite in northwestern Corsica for U-Pb zircon dating, including three quartz monzonites, one monzogranite and one monzogabbro enclave. Three quartz monzonite samples $11 \mathrm{CO} 57 \quad\left(42^{\circ} 38^{\prime} 24.6^{\prime \prime} \mathrm{N}, \quad 8^{\circ} 59^{\prime} 58.6^{\prime} \mathrm{E}\right), \quad 11 \mathrm{CO} 58$ $\left(42^{\circ} 36^{\prime} 42.5^{\prime} \mathrm{N}, 8^{\circ} 52^{\prime} 52.3^{\prime} \mathrm{E}\right)$ and $11 \mathrm{CO} 60\left(42^{\circ} 36^{\prime} 06.5^{\prime} \mathrm{N}, 8^{\circ} 50^{\prime} 29.4^{\prime} \mathrm{E}\right)$ have 
similar mineral compositions, consisting of ca. $20-40 \%$ alkali-feldspar, ca. $20-45 \%$ plagioclase, ca. $10-15 \%$ quartz, ca. $5-10 \%$ biotite and ca. $1-5 \%$ hornblende. Clinopyroxene is visible and occurs as small relics in hornblende. Accessory minerals include titanite (usually visible with the naked eye), apatite, zircon, allanite, Ilmenite and sulfides. A monzogranite sample 12FR34 $\left(42^{\circ} 34^{\prime} 13.9^{\prime} \mathrm{N}, 8^{\circ} 45^{\prime} 19.4^{\prime} \mathrm{E}\right)$ was collected from the coast of Calvi city. It consists of ca. $40 \%$ alkali feldspar, ca. $25 \%$ plagioclase, ca. $30 \%$ quartz and ca. $5 \%$ biotite, as well as accessory minerals including titanite, allanite and zircon. In addition, a monzogabbro enclave sample $11 \mathrm{CO} 59\left(42^{\circ} 35^{\prime} 52.9^{\prime} \mathrm{N}\right.$, $\left.8^{\circ} 52^{\prime} 19.6^{\prime} E\right)$ associated with the monzogranite was also collected for SIMS U-Pb zircon dating. It consists of ca. $50 \%$ plagioclase, ca. $15 \%$ alkali-feldspar, ca. $25 \%$ biotite and ca. $10 \%$ clinopyroxene as well as trace amount of quartz and hornblende. Accessory minerals include titanite, apatite, zircon, ilmenite and sulfides.

\section{Analytical methods}

Zircon concentrates were separated from ca. $2 \mathrm{~kg}$ of rock samples using standard density and magnetic separation techniques. Zircon grains were mounted in epoxy mounts that were then polished to section the crystals in half for analysis. All zircons were documented with transmitted and reflected light micrographs as well as cathodoluminescence $(C L)$ images to reveal their internal textures, and the mount was vacuum-coated with high-purity gold to 
reach $<20 \Omega$ resistance prior to SIMS analyses.

Measurements of $\mathrm{U}, \mathrm{Th}$ and $\mathrm{Pb}$ isotopes were conducted using a Cameca IMS-1280 SIMS at the Institute of Geology and Geophysics, Chinese Academy of Sciences in Beijing. The instrument description and analytical procedure can be found in Li et al. (2009), and only a brief summary is described here. The primary $\mathrm{O}_{2}^{-}$ion beam spot is about $20 \times 30 \mu \mathrm{m}$ in size. Positive secondary ions were extracted with a $10 \mathrm{KV}$ potential. Oxygen flooding was used to increase the $\mathrm{O}_{2}$ pressure to ca. $5 \times 10^{-6}$ Torr in the sample chamber, enhancing the secondary $\mathrm{Pb}^{+}$sensitivity to a value of $25 \mathrm{cps} / \mathrm{nA} / \mathrm{ppm}$ for zircon. In the secondary ion beam optics, a $60 \mathrm{eV}$ energy window was used, together with a mass resolution of ca. 5400 (at $10 \%$ peak height), to separate $\mathrm{Pb}^{+}$peaks from isobaric interferences. A single electron multiplier was used in ion-counting mode to measure secondary ion beam intensities by peak jumping mode. Analyses of the standard zircon TEMORA 2 were interspersed with unknown grains. Each measurement consists of 7 cycles. $\mathrm{Pb} / \mathrm{U}$ calibration was performed relative to zircon standard TEMORA $2\left({ }^{206} \mathrm{~Pb} /{ }^{238} \mathrm{U}\right.$ age $=417 \mathrm{Ma}$, Black et al., 2004); $U$ and Th concentrations were calibrated against zircon standard 91500 (Th $=29$ ppm, and $U=81$ ppm, Wiedenbeck et al., 1995). A long-term uncertainty of $1.5 \%\left(1 \sigma\right.$ RSD) for ${ }^{206} \mathrm{~Pb} /{ }^{238} \mathrm{U}$ measurements of the standard zircons was propagated to the unknowns (Li et al., 2010), despite that the measured ${ }^{206} \mathrm{~Pb} /{ }^{238} \mathrm{U}$ error in a specific session is generally $\leq 1 \%$ (1 $\sigma \mathrm{RSD}$ ). Measured compositions were corrected for common $\mathrm{Pb}$ using non-radiogenic 
${ }^{204} \mathrm{~Pb}$. Corrections are sufficiently small to be insensitive to the choice of common $\mathrm{Pb}$ composition, and an average of present-day crustal composition (Stacey and Kramers, 1975) is used for the common $\mathrm{Pb}$ assuming that the common $\mathrm{Pb}$ is largely surface contamination introduced during sample preparation. Data reduction was carried out using the Isoplot/Ex v. 2.49 program (Ludwig, 2001). Uncertainties on individual analyses in data tables are reported at $1 \sigma$ level; Concordia U-Pb ages are quoted with $95 \%$ confidence interval, except where noted otherwise.

In order to monitor the external uncertainties of SIMS U-Pb zircon dating calibrated against TEMORA 2 standard, an in-house zircon standard Qinghu was alternately analyzed as an unknown together with other unknown zircons. Twenty-two measurements on Qinghu zircon (Appendix Table 1) yield a Concordia age of $160 \pm 1 \mathrm{Ma}$, which is identical within error with the recommended value of $159.5 \pm 0.2 \mathrm{Ma}$ (Li et al. 2013).

\section{Analytical results}

\subsection{Zircon U-Pb age of metamorphic septa}

\subsubsection{Solenzara-Fautea metamorphic septum (sample 11CO21)}

Zircons from this leucosome sample are stubby, transparent, $50-100 \mu \mathrm{m}$ in length, and have aspect ratios of $1: 1$ to $2: 1$. They can be generally subdivided into two groups in terms of their morphology CL image features. The group 1 zircons are mostly oval in shape, showing chaotic textures under $\mathrm{CL}$, whereas 
the group 2 zircons are idiomorphic in shape, showing euhedral concentric zoning under $\mathrm{CL}$ (Fig. 2). Eighteen analyses were conducted on 18 zircons during a single analytical session (Appendix Table 1), with nine measurements for each group. The group 1 zircons have $U$ ranging from 404 to $999 \mathrm{ppm}$, Th from 10 to $42 \mathrm{ppm}$, and $\mathrm{Th} / \mathrm{U}$ between 0.01 and 0.09 . Common $\mathrm{Pb}$ is low; value for $f_{206}$ (the proportion of common ${ }^{206} \mathrm{~Pb}$ in total measured ${ }^{206} \mathrm{~Pb}$ ) is lower than $0.8 \%$. Ratios of ${ }^{206} \mathrm{~Pb} /{ }^{238} \mathrm{U}$ and ${ }^{207} \mathrm{~Pb} /{ }^{235} \mathrm{~Pb}$ agree internally within the analytical precision, yielding a Concordia age of $345 \pm 3 \mathrm{Ma}$ (MSWD of concordance $=$ 0.85) (Fig. 3a). Morphological and textural features and low $\mathrm{Th} / \mathrm{U}$ ratios $(<0.1)$ indicate that the group 1 zircons are most likely grown from the metamorphic aqueous fluid (Corfu et al., 2003; Xia et al., 2009) during migmatization. Thus, the age of $345 \pm 3 \mathrm{Ma}$ is interpreted as the timing of migmatization. The group 2 zircons have $\mathrm{U}$ ranging from 97 to $579 \mathrm{ppm}$, Th from 61 to $283 \mathrm{ppm}$, and $\mathrm{Th} / \mathrm{U}$ between 0.21 and 1.17. Common $\mathrm{Pb}$ is low, with $f_{206}<0.3 \%$. Apart from one discordant analysis (spot 16) that yields a ${ }^{207} \mathrm{~Pb} /{ }^{206} \mathrm{~Pb}$ date of $2099 \pm 6 \mathrm{Ma}(1 \sigma)$, the remaining 8 analyses give concordant $\mathrm{U}-\mathrm{Pb}$ ages between $434 \pm 6 \mathrm{Ma}$ and $630 \pm 10 \mathrm{Ma}(1 \sigma)$. These old zircons are interpreted as inherited crystals of previous magmatism in terms of their morphological and textural features.

\subsubsection{Vignola metamorphic septum (samples 11C094A and 11CO94C)}

Zircons from these two leucosome samples are similar in morphology. They are mostly elongated, euhedral, 100-200 $\mu \mathrm{m}$ in length, and have aspect ratios 
of $2: 1$ to $3: 1$. About two thirds of zircon grains are transparent to semi-transparent, and the remaining zircons are poorly transparent. Magmatic concentric zoning is common under $\mathrm{CL}$.

Seventeen analyses were conducted on 17 zircons from sample 11CO94A during a single analytical session (Appendix Table 1). They have highly variable U (432-11514 ppm) and Th (63-613 ppm) contents. Their Th/U ratios are between $0.01-0.29$, with 12 zircons having $T h / U<0.1$. Values for $f_{206}$ are between $0.01 \%$ and $1.37 \%$. All the analyses define a discordia line on the conventional U-Pb concordia plot (Fig. 3b), with an upper-intercept age of $345 \pm$ 9 Ma. Apart from 5 clearly discordant analyses, the remaining 12 analyses yield a U-Pb Concordia age of $345 \pm 3 \mathrm{Ma}$ (MSWD of concordance $=0.24$ ), which is interpreted as the best estimate of the zircon formation age.

Nineteen analyses are conducted on 18 zircons from sample 11CO94C. Values for $f_{206}$ are $<0.8 \%$, apart from one analysis having $f_{206}=1.58 \%$. Spots $14 \mathrm{c}$ and $14 \mathrm{r}$ were analyzed respectively on the core and rim of single crystal. The core and rime give discordant $\mathrm{U}-\mathrm{Pb}$ results, with ${ }^{207} \mathrm{~Pb} /{ }^{206} \mathrm{~Pb}$ age of $1938 \pm$ $7 \mathrm{Ma}(1 \sigma)$ and $1137 \pm 19 \mathrm{Ma}(1 \sigma)$, respectively. Nine euhedral zircons have variable $U$ (648-4852 ppm) and Th (99-593 ppm) contents, and Th/U ratio between 0.06-0.49 (Table 1). They are all concordant, yielding a U-Pb Concordant age of $345 \pm 3$ Ma (MSWD of concordance $=0.01$ ) (Fig. 3c). This age is interpreted as the timing of these euhedral zircons crystallized from the leucocratic melts. Eight anhedral zircons have $U=200-3031 \mathrm{ppm}, \mathrm{Th}=40-383$ 
ppm, and $\mathrm{Th} / \mathrm{U}=0.04-0.50$ (Appendix Table 1 ). They give nearly concordant U-Pb results, with ${ }^{206} \mathrm{~Pb} /{ }^{238} \mathrm{U}$ age between 534 and $618 \mathrm{Ma}$ (Fig. 3c). These euhedral zircons (including the spot 14) are interpreted as inherited origin.

\subsubsection{Belgodère metamorphic septum (samples $11 \mathrm{CO} 67$ and 11CO66)}

Zircons from the leucosome sample 11CO67 are euhedral, transparent, $100-150 \mu \mathrm{m}$ in length, and have aspect ratios of ca. 2:1, but a few of zircons are anhedral. Magmatic concentric zoning is common under CL. Twenty-two analyses were conducted on 22 zircons during a single analytical session (Appendix Table 1), with 16 and 6 measurements for the euhedral and anhedral zircons, respectively. Sixteen euhedral zircons have wide ranges of $U$ (387-4904 ppm) and Th (49-1151 ppm) contents. Their Th/U ratios are between 0.03 and 0.90 , with nine zircons having $T h / U<0.1$. Values for $f_{206}$ are all lower than $0.9 \%$ (mostly $<0.1 \%$ ). All the U-Pb measurements are variably discordant (Fig. 3d). A linear fit of all 16 analyses on a U-Pb concordia plot yields an upper and lower-intercept age of $345 \pm 11 \mathrm{Ma}$ and $42 \pm 30 \mathrm{Ma}$, respectively. The upper-intercept age is well constrained by two nearly concordant analyses with a mean ${ }^{206} \mathrm{~Pb} /{ }^{238} \mathrm{U}$ age of $347 \pm 7 \mathrm{Ma}$, which is interpreted as the formation age of these euhedral zircons. The lower-intercept age of $42 \pm 30$ Ma likely reflects the Alpine tectonothermal overprinting that caused radiogenic $\mathrm{Pb}$ loss to varying degrees. Six euhedral zircons are all concordant in U-Pb isotopic system, yielding ${ }^{206} \mathrm{~Pb} /{ }^{238} \mathrm{U}$ age between 488 and $619 \mathrm{Ma}$, which are interpreted 
as inherited origin.

Seventeen analyses were conducted on 17 zircons from sample $11 \mathrm{CO66}$ (Appendix Table 1). It is a magmatically foliated granodiorite, although named as the Belgodère "orthogneiss" (Paquette et al., 2003). This rock does not exhibit a post-solidus foliation. The preferred planar mineral orientation probably developed during the granodiorite intrusion into the Belgodère migmatite. Zircons have wide ranges of $U$ (1392-4613 ppm) and Th (445-692 ppm) contents and Th/U ratio of $0.10-0.48$. Values for $f_{206}$ are mostly $<0.8 \%$, with a few grains having slightly high common $\mathrm{Pb}\left(f_{206}=1.0-2.7 \%\right)$. All the analyses are plotted along the U-Pb Concordia (Fig. 3e), with a wide range of ${ }^{206} \mathrm{~Pb} /{ }^{238} \mathrm{U}$ ages between 119 and $339 \mathrm{Ma}$. In view of the typical magmatic morphology for all the analyzed zircons, the variable U-Pb dates are interpreted as result of radiogenic $\mathrm{Pb}$ loss to varying degrees, and the maximum date of $339 \pm 5 \mathrm{Ma}(1 \sigma)($ spot@22) approximates the crystallization age of this sample. This age is consistent with previously reported TIMS U-Pb zircon age of $338.1 \pm$ 0.8 Ma for the Belgodère "orthogneiss" (Paquette et al., 2003), providing a minimum age constraint on the metamorphism of the Belgodère septum.

\subsection{Zircon U-Pb age of Calvi-Ile Rousse Mg-K intrusions}

\subsubsection{Quartz monzonites (11C057, 11CO58 and 11C060)}

Zircons from sample $11 \mathrm{CO} 57$ are mostly euhedral, transparent, 100-150 $\mu \mathrm{m}$ in length, and have aspect ratios of $1: 1$ to $2: 1$. Magmatic concentric zoning 
is common under $\mathrm{CL}$ (Fig. 2). Fourteen analyses are conducted on 14 zircons from this sample. They have moderate $U$ (326-689 ppm) and Th (75-594 ppm) contents, and $\mathrm{Th} / \mathrm{U}$ ratio of $\mathbf{0 . 2 3 - 0 . 8 9}$ (Appendix Table 2). Values for $f_{206}$ are all $<0.5 \%$. All analyses have concordant $\mathrm{U}-\mathrm{Pb}$ ages within analytical errors (Fig. 4a), yielding a U $-\mathrm{Pb}$ Concordia age of $331 \pm 3 \mathrm{Ma}$ (MSWD of concordance $=$ $0.19)$ that is interpreted as the crystallization age for sample $11 \mathrm{CO} 57$.

Zircons from sample 11CO58 are mostly euhedral, transparent, 100-200 $\mu \mathrm{m}$ in length, and have aspect ratios of 2:1 to $3: 1$. Magmatic concentric zoning is common under $\mathrm{CL}$ (Fig. 2). Fifteen analyses are conducted on 15 zircons from this sample. They have moderate $U$ (177-814 ppm) and Th (166-725 ppm) contents, and $\mathrm{Th} / \mathrm{U}$ ratio of $0.48-1.29$ (Appendix Table 2). Common $\mathrm{Pb}$ is very low, values for $f_{206}$ are all $<0.3 \%$. All the measured $\mathrm{Pb} / \mathrm{U}$ ratios are concordant within analytical errors (Fig. 4b), yielding a U-Pb Concordia age of $329 \pm 3 \mathrm{Ma}$ (MSWD of concordance $=0.53$ ). This age is interpreted as the best estimate of the crystallization age for sample $11 \mathrm{CO} 58$.

Fifteen analyses are conducted on 14 zircons from sample 11CO60, with $\mathrm{U}$ $=153-952 \mathrm{ppm}, \mathrm{Th}=102-591 \mathrm{ppm}$, and Th/U = 0.11-1.46 (Appendix Table 2). Common $\mathrm{Pb}$ is very low, values for $f_{206}$ are all $<0.2 \%$. All $\mathrm{U}-\mathrm{Pb}$ results are concordant within errors (Fig. 4c), yielding a U-Pb Concordia age of $328 \pm 3 \mathrm{Ma}$ (MSWD of concordance $=0.06$ ). This age is considered as the best estimate for the crystallization age of sample 11CO60, indistinguishable within errors from the age of samples $11 \mathrm{CO} 57$ and $11 \mathrm{CO} 58$. 


\subsubsection{Monzogranite (12FR34)}

Zircons from this sample are euhedral, transparent, 100-200 $\mu \mathrm{m}$ in length, and have aspect ratios of 2:1 to $3: 1$. In CL image magmatic concentric zoning is common (Fig. 2). Eighteen analyses are conducted on 18 zircons from this sample. They have variable $U(175-2041 \mathrm{ppm})$ and Th $(216-2245 \mathrm{ppm})$ contents, and Th/ $\mathrm{U}$ ratio of $0.39-2.47$ (Appendix Table 2). Values for $f_{206}$ are mostly $<0.7 \%$, except for two analyses (spot @5 and @7) that give relatively high value of $f_{206}(2.11-2.52 \%)$. All but one analyses (spot 1) give the measured $\mathrm{Pb} / \mathrm{U}$ ratios indistinguishable within analytical errors (Fig. 4d), yielding a $\mathrm{U}-\mathrm{Pb}$ Concordia age of $331 \pm 2 \mathrm{Ma}$ (MSWD of concordance $=0.45$ ). This age is interpreted as the best estimate of the crystallization age for sample 12FR34. Spot 1 give the highest $\mathrm{U}$ content (2041 ppm) and the youngest U-Pb date of ca. $302 \mathrm{Ma}$ due to radiogenic $\mathrm{Pb}$ loss.

\subsubsection{Monzogabbro enclave (11CO59)}

Zircons from this sample are mostly subhedral to euhedral, transparent, 50-120 $\mu \mathrm{m}$ in length, and have aspect ratios of 1:1 to 2:1. They are characterized by patchy texture under CL (Fig. 2). Fourteen analyses are conducted on 14 zircons. They have moderate $U(236-646 \mathrm{ppm})$ and Th (113-901 ppm) contents; Th/U ratio varies from 0.33 to 2.27 (Appendix Table 2). Common $\mathrm{Pb}$ is very low, values for $f_{206}$ are between $0.09 \%$ and $0.34 \%$. Thirteen 
of $14 \mathrm{U}-\mathrm{Pb}$ analyses are concordant within errors (Fig. 4e), yielding a U-Pb Concordia age of $330 \pm 3 \mathrm{Ma}$ (MSWD of concordance $=0.58$ ). This age is considered as the best estimate for the crystallization age of this monzogabbro enclave sample. Spot @1 gives a clearly younger date of ca. 290 Ma than others due possibly to radiogenic $\mathrm{Pb}$ loss.

Overall, SIMS U-Pb zircon dating results give consistent crystallization age of ca. $330 \mathrm{Ma}$ (within analytical errors) for different lithologies from the Calvi-Ile Rousse Mg-K pluton.

\section{Discussion}

\subsection{Timing of the Variscan migmatization in Corsica}

Precise radiometric age determinations are rare for the migmatization associated with amphibolite-facies metamorphism in the Variscan high-grade basements in Corsica. Giacomini et al. (2008) reported a LA-ICPMS U-Pb zircon age of $338 \pm 4$ Ma for a paragneiss sample from Punta Chiappa, in the Porto Vecchio septum, which was interpreted as the time of regional amphibolite-facies metamorphism. Migmatites are broadly intercalated I shall say "Migmatite enclose various gneiss corresponding to restite of the protoliths that produced the migmatite. These gneiss were widely re-equilibrated under amphibolite-facies conditions, but they may also preserve higher metamorphic conditions such as those recorded in HP granulites or eclogites (Rouire et al., 1993; Giacomini et al. 2008; Rossi et al., 2009b). with the gneisses 
sequences in this area. Thus, migmatization occurred synchronously with the amphibolite-facies metamorphism observed in the gneiss. The group 1 zircons from the Solenzara-Fautea migmatite sample $11 \mathrm{CO} 21$ are typical of metamorphic origin in terms of their morphological and textural features and extremely low $\mathrm{Th} / \mathrm{U}$ ratio of $<0.1$. The Concordia $\mathrm{U}-\mathrm{Pb}$ age of $345 \pm 3 \mathrm{Ma}$ for the group 1 metamorphic zircons provides a precise age constraint on migmatization associated with amphibolite-facies metamorphism in this region. Zircons from two migmatite samples (11C094A and 11C094C) of the Vignola metamorphic complex are also dated synchronously at $345 \pm 3 \mathrm{Ma}$, apart from a few inherited ancient zircons recorded in sample $11 \mathrm{CO}$ (1) $\mathrm{C}$. It noted that the ca. 345 Ma zircons are generally characterized by euhedral shape and magmatic concentric zoning. Thus these zircons are more likely magmatic than metamorphic in origin. Such "magmatic zircons" are commonly seen in migmatites, and they are considered to have grown in contact with a melt phase (Corfu et al., 2003). This is consistent with the granitic compositions of these leucosomes (11C094A and 11C094C) from which zircons were separated. Therefore, the SIMS U-Pb zircon age of ca. $345 \mathrm{Ma}$ for these "magmatic zircons" is interpreted as the timing of crystallization of the granitic leucosomes, providing the best estimate of formation of the migmatization in the Vignola metamorphic septum.

Zircons from the migmatite leucosome (11C067) of the Belgodère metamorphic septum are complicated in morphology. Six anhedral zircons 
dated at 488-619 Ma are likely inherited in origin. The remaining 16 euhedral zircons are characterized by magmatic concentric zoning, similar in genesis to those from the Vignola migmatite leucosomes. These zircons are highly discordant, with a lower-intercept age of $30 \pm 19 \mathrm{Ma}$, reflective of Alpine tectonothermal overprinting. The upper-intercept age of $343 \pm 11 \mathrm{Ma}$, identical to the mean ${ }^{206} \mathrm{~Pb} /{ }^{238} \mathrm{U}$ age of $347 \pm 7 \mathrm{Ma}$ for two least-discordant analyses, give the best estimate of crystallization age of these euhedral zircons. Despite relatively large uncertainty, this age is consistent with the crystallization age of ca. $339 \mathrm{Ma}$ for the orthogneiss sample (11CO66) that intruded in to the migmatite.

In summary, our new SIMS U-Pb zircon dating results indicate that the regional migmatization under amphibolite-facies conditions occurred synchronously at ca. $345 \mathrm{Ma}$ in Corsica. This migmatization event is coeval with the formation of a few Al-rich granitoids dated at ca. 345-347 Ma (Paquette et al., 2003), and the SHRIMP U-Pb zircon age of $345 \pm 5 \mathrm{Ma}$ for pyrigarnites from the Porto-Vecchio metamorphic septum (Rossi et al., 2009). YES, WHY NOT PUT THIS SENTENCE LINE 432 AS IT CONCERNS PORTO VECCHIO AND NOT BELGODERE?

\subsection{Emplacement age of the U1 Mg-K magmatism}

Radiometric dating works were previously conducted on the U1 Mg-K rocks by using $\mathrm{Rr}-\mathrm{Sr}$ whole-rock isochron, biotite ${ }^{40} \mathrm{Ar} /{ }^{39} \mathrm{Ar}$ and conventional U-Pb 
zircon techniques. Maluski (1976) first reported a high-temperature biotite ${ }^{40} \mathrm{Ar} /{ }^{39} \mathrm{Ar}$ age of $331 \pm 10 \mathrm{Ma}$ for a Mg-K granite from Cargese, whilst Cocherie (1984) obtained an $\mathrm{Rb}-\mathrm{Sr}$ isochron age of $298 \pm 14 \mathrm{Ma}$ for a group of rocks ranging in composition from monzodiorites to monzogranites. Rossi et al. (1988) reported a U-Pb zircon age of $350+36 /-18 \mathrm{Ma}$ for the Calvi monzogranite. By using single-zircon $\mathrm{Pb}-\mathrm{Pb}$ evaporation technique, Cocherie et al. (1992) reported a zircon $\mathrm{Pb} / \mathrm{Pb}$ age of $322 \pm 12 \mathrm{Ma}$ for the Calvi monzogranite. More recently, Paquette et al. (2003) obtained an ID-TIMS U-Pb zircon age of $337 \pm 1$ Ma for a porphyritic granite from Calvi pluton, and $338 \pm 2$ Ma for a subvolcanic granite from Porto Agro. Therefore, it is now generally accepted that the U1 Mg-K intrusions were emplaced at ca. $340 \mathrm{Ma}$.

Our new SIMS U-Pb zircon dating results give consistent crystallization ages of ca. $330 \mathrm{Ma}$ for various rock types including quartz monzonite, monzogranite and monzogabbro enclave from the Calvi-lle Rousse Mg-K pluton, indicating that both the mantle- and crust-derived $\mathrm{Mg}-\mathrm{K}$ magmatic rocks are coeval. This is consistent with the field observations that the mafic microgranular enclaves (MMEs) mostly range from angular to oval in shape, locally form dyke-like trails that progressively thin toward their terminations with the host granitoid; several of the MMEs are themselves host to granitoid materials, some of which is entirely enclosed within the MME.

It is noteworthy that our new SIMS U-Pb zircon age results for the Calvi-Ile Rousse pluton are about 8 m.y. younger than two ID-TIMS U-Pb zircon ages of 
ca. $338 \mathrm{Ma}$ (Paquette et al., 2003). The previous ID-TIMS zircon analyses are all discordant; the crystallization ages of ca. $338 \mathrm{Ma}$ were obtained by upper-intercept of the discordia line with the U-Pb Concordia curve. We noticed that the measured ID-TIMS zircon ${ }^{207} \mathrm{~Pb} /{ }^{206} \mathrm{~Pb}$ ages are highly variable, ranging from 325 to $622 \mathrm{Ma}$ for the Mg-K rocks (Paquette et al., 2003). Therefore, the reported upper-intercept ages of ca. $338 \mathrm{Ma}$ might be problematic due to presence of inherited radiogenic $\mathrm{Pb}$, and/or complicated processes of radiogenic $\mathrm{Pb}$ loss. Nonetheless, verification of this age discrepancy between SIMS and ID-TIMS methods and precise dating for other $\mathrm{Mg}-\mathrm{K}$ plutons necessitate further investigations.

The Mg-K magmatic suites were emplaced after formation of the high-grade metamorphism, and are thought to be formed during an early stage of the collapse of the Variscan orogen (e.g., Franke, 1989; Ferré and Leake, 2001). In contrast to the previous isotopic dating results yielding a nearly overlapped time interval between the amphibolite-facies metamorphism and Mg-K magmatism at ca. $340 \mathrm{Ma}$, our new SIMS U-Pb zircon age results demonstrate a time interval of ca. 15 m.y. between the regional amphibolite-facies crustal anatexis at ca. $345 \mathrm{Ma}$ to mantle melting as seen the mafic $\mathrm{Mg}-\mathrm{K}$ magmatism at ca. $330 \mathrm{Ma}$. This is consistent with the field relationship of the Calvi-Ile Rousse $\mathrm{Mg}-\mathrm{K}$ suite rocks intrusive into the Belgodère metamorphic Complex (Rossi et al., 2001, and our field observations). 


\subsection{Geodynamic implications}

On the basis of recent petro-structural works, the Variscan tectonic framework of Corsica can be divided into four NW-SE trending domains (Faure et al., 2014, Fig. 6). Namely, from SW to NE: (1) a Western Domain formed by polyphase Variscan metamorphic rocks, including Topiti, Vignola, Zicavo, Porto Vecchio, and Solenzara-Fautea septa, in which top-to-the-SW D1 shearing, followed by D2 top-to-the-SE shearing and retrogression dominates; (2) the Argentella Neoproterozoic basement and its Paleozoic sedimentary cover undeformed by the Variscan phases; (3) a northeastern domain represented by the Belgodère septum, characterized by polyphase east-directed structures; (4) the Agriates-Tenda Neoproterozoic basement and its Paleozoic sedimentary cover. The primary arrangement and size of these four Variscan domains, and their S1 and S2 boundaries have been probably modified by Alpine tectonics, however the relative position of one domain with respect to its neighbors might have been generally preserved since large strike-slip faults are not recognized. The southwestern and northeastern boundaries of the Argentella domain correspond to two sutures zones. The Western and Eastern sutures can be correlated with the Late Silurian-Early Devonian eo-Variscan, and Early Carboniferous Le Conquet sutures described in the Armorican Massif, respectively (e.g. Faure et al., 2005, 2008, 2009; Ballèvre et al., 2009). The Western domain extends in Northern Sardinia where similar metamorphic rocks 
and migmatites have been described in the high-grade metamorphic complex (e.g. Lardeaux et al. 1994; Franceschelli et al. 2007; Giacomini et al. 2008; Rossi et al. 2009, Cruciani et al. 2013, and references therein). This Western domain is also comparable with the Maures-Tanneron massif (e.g. Corsini and Rolland 2009; Rolland et al. 2009).

Giacomini et al. (2008) carried out comprehensive investigations of structural geology, metamorphic petrology and geochronology for the Fautea-Solenzara metamorphic septum in southeastern Corsica, and proposed a tectono-metamorphic framework for the lower crust sequences in this area. The high-pressure and high-temperature granulite-facies metamorphism was dated at $361 \pm 3 \mathrm{Ma}$, whilst a younger age group of $332 \pm 4$ Ma was also obtained from the same felsic granulite samples. The paragneisses that recorded the middle crustal-level, amphibolite-facies metamorphism were dated at $338 \pm 4 \mathrm{Ma}$. These authors interpreted the high-pressure (up to $1.8 \mathrm{GPa}$ ) and high temperature (up to $1000^{\circ} \mathrm{C}$ ) granulite facies metamorphism was attributed to the continental subduction related to the early stages of convergence during which the slab break-off and hot asthenosphere upwelling possibly provided the thermal input to the base of the subducting crust. The diachronism between granulite and amphibolite metamorphic events at ca. 340-330 Ma was attributed to supra-subduction granulite exhumation, migmatization under amphibolite-facies conditions at the middle crustal level, and Mg-K magmatic pulses at ca. $338 \mathrm{Ma}$ (Paquette et al., 
2003). It is noteworthy, however, that the ages of ca. $360 \mathrm{Ma}$ and ca. $330 \mathrm{Ma}$ for granulite-facies metamorphism reported by Giacomini et al. (2008) might not be well constrained in view of their LA-ICPMS U-Pb zircon dataset. Fist, their four LA-ICPMS U-Pb measurements for standard zircon ZC-0213 yield ${ }^{206} \mathrm{~Pb} /{ }^{238} \mathrm{U}$ ages ranging from $297 \pm 3 \mathrm{Ma}$ to $317 \pm 4 \mathrm{Ma}(1 \sigma)$, averaging at $305 \pm 14 \mathrm{Ma}$ ( $95 \%$ confidence interval, MSWD $=5.4)$. Such a large age uncertainty could not statistically distinguish an age span of ca. 30 m.y. for their ca. 360-330 Ma metamorphic zircons. Second, we reprocessed the LA-ICPMS U-Pb dates for two felsic granulite samples (C1 and C6) from Fautea (Giacomini et al., 2008). Excluding the inherited zircons $(>380 \mathrm{Ma}$ ), the remaining 51 analyses give a wide range of ${ }^{206} \mathrm{~Pb} /{ }^{238} \mathrm{U}$ ages from $42 \mathrm{Ma}$ to $368 \mathrm{Ma}$, forming a major peak at ca. $360 \mathrm{Ma}$ and two subordinate peaks at ca. 328-336 Ma and ca. $299 \mathrm{Ma}$ (Fig. 5). Thus, we prefer to consider that the granulite-facies metamorphism likely occurred at ca. $360 \mathrm{Ma}$, whilst the second and third metamorphic events at ca. $330 \mathrm{Ma}$ and ca. $299 \mathrm{Ma}$, might correspond to recrystallization events. Rossi et al. (2009) reported a SHRIMP U-Pb age of $345 \pm 5$ Ma for metamorphic zircon rims from the Fautea pyrigarnite, and interpreted it as postdating the peak-metamorphism. This SHRIMP U-Pb age is well coincident with the migmatization age of $\sim 345 \mathrm{Ma}$ in this study, reflecting a retrogressive P-T evolution from high pressure-temperature granulite- to amphibole-facies metamorphism of the Fautea-Solenzara septum.

Our precise SIMS U-Pb zircon age results reveal a synchronous regional 
migmatization event under amphibolite-facies conditions at ca. $345 \mathrm{Ma}$, which is ca. 15 m.y. younger than the timing of granulite-facies metamorphism. Furthermore, the mantle- and lower crust-derived high $\mathrm{Mg}-\mathrm{K}$ suite rocks are emplaced at ca. $330 \mathrm{Ma}$. These precise age results invalidate the coincidence of amphibolite-facies metamorphism and high $\mathrm{Mg}-\mathrm{K}$ magmatism as previously proposed. Therefore, we suggest three major discrete tectonothermal events between ca. $360 \mathrm{Ma}$ and ca. $330 \mathrm{Ma}$, i.e., (1) the granulite-facies metamorphism at ca. $360 \mathrm{Ma}$, (2) the migmatization and amphibolite-facies metamorphism at ca. $345 \mathrm{Ma}$, and (3) the $\mathrm{Mg}-\mathrm{K}$ magmatism at ca. $330 \mathrm{Ma}$. Thus, a similar cause accounting for the migmatization process in the entire Variscan Corsica segment should be proposed. One of the main questions is the source of heat necessary to trigger crustal melting. In collisional orogen, it is often argued that crustal thickening as it increases the concentration of radiogenic elements would promote the partial melting of metapelites and quartz-feldspar orthogneiss. When thermal relaxation proceeds, numerous plutonic rocks would emplace during the late- to post-orogenic stages. Another view considers that the internal crustal heat, even assisted by fluids, in not sufficient to trigger crustal melting. Hence a mantle source of heat must be considered. This explanation requires the thinning of subcontinental mantle lithosphere and its replacement by a hot asthenospheric mantle that might be achieved by various mechanisms such as slab break-off, delamination, magmatic underplating or convective ablation. Tentatively, we speculate here 
that such a mechanism might be responsible for the development of the widespread migmatization found in the Corsican Variscan belt whatever the tectonic domains. After the main continental amalgamation was completed in Early Carboniferous, the lithosphere mantle was thinned due possibly to the slab break-off and heat transfer from the asthenosphere that triggered melting of the middle crust, giving rise to the development of anatectic high-Al granite-migmatitic complexes throughout the entire belt. A similar interpretation has been suggested for the Massif central-Massif Armoricain segment of the Variscan belt (Faure et al., 2010). The Mg-K plutonism is well developped in the eastern part of the Variscan belt including the Vosges, Bohemia, and Corsica-Sardinia (e.g. Schaltegger and Corfu, 1992; Rossi and Cocherie, 1991; Rossi et al., 2005; Janoušek et al., 2000; Ferré and Leake, 2001; Tabaud, 2012). In agreement with petrological constraints, a mantle contribution is necesary to produce these $\mathrm{Mg}-\mathrm{K}$ magmas.

We propose here a revised geochronological scenario for the post-collision orogenic evolution of the Variscan belt in Corsica. A tearing of the subducting oceanic lithosphere initiates the asthenosphere rise to fill the void and causes high pressure and temperature granulite-facies metamorphism of the overlying continental crust at ca. $360 \mathrm{Ma}$. The lithospheric thinning proceeds and finally triggers the break-off of the subducting slab, resulting in exhumation of the subducted crust to the middle crustal-level and forming the migmatites and Al-rich granitoids by crustal anatexis under amphibolite-facies conditions at ca. 
$345 \mathrm{Ma}$. The rise of hot asthenosphere due to slab break-off will heat up the metasomatised continental lithosphere. Partial melting of the enriched mantle generated high $\mathrm{Mg}-\mathrm{K}$ mafic magmas that were injected into the lower crust and triggered its extensive melting at ca. $330 \mathrm{Ma}$. Interactions between mafic and felsic magmas under high-pressure conditions (ca. 1.5 GPa) were responsible for the common high Mg-K characteristics of both magma suites (Ferré and Leake, 2001).

\section{Conclusions}

We draw the following conclusions based on our precise SIMS U-Pb zircon dating of migmatites formed under amphibolite-facies metamorphic conditions and the Calvi-lle Rousse high $\mathrm{Mg}-\mathrm{K}$ intrusions from the Variscan Orogen in Corsica.

(1) Migmatites from the Solenzara-Fautea septum in southeastern Corsica, the Vignola septum in southwestern Corsica and the Belgodère septum in northern Corsica are formed synchronously at ca. $345 \mathrm{Ma}$, providing a robust constraint on the timing of the regional migmatization under amphibolite-facies conditions.

(2) Various rock types including quartz monzonite, monzogranite and monzogabbro enclave from the Calvi-lle Rousse pluton are dated synchronously at ca. $330 \mathrm{Ma}$, indicating that both mantle- and crust-derived high $\mathrm{Mg}-\mathrm{K}$ magmatic rocks are coeval. 
(3) We propose here a revised geochronological scenario for the late-orogenic evolution of the Variscan belt of Corsica. After completion of the continental amalgamation in Early Carboniferous, the lithospheric thinning and break-off of the subducting slab result in exhumation of the subducted crust to the middle crustal-level, forming extensive crustal antexis at ca. $345 \mathrm{Ma}$. The rise of hot asthenosphere causes partial melting of the metasomatised lithosphere mantle, generating the $\mathrm{U} 1 \mathrm{high} \mathrm{Mg}-\mathrm{K}$ magmatism at ca. $330 \mathrm{Ma}$.

\section{Acknowledgement}

We are deeply indebted to Dr. Philippe Rossi for his assistance during field work and many helpful discussions in this study. We also thank Y.Y. Gao and X.Y. Jiang for their assistance in SIMS zircon U-Pb analyses, This work was supported by the National Natural Science foundation of China (grant 41273070). 
References

Ballèvre, M., Bosse, V., Ducassou, C., Pitra, P., 2009. Paleozoic history of the Armorican Massif: models for the tectonic evolution of the suture zones. C.R. Geoscience 341, 174-201.

Black, L.P., Kamo, S.L., Allen, C.M., Davis, D.W., Aleinikoff, J.N., Valley, J.W., Mundil, R., Campbel, I.H., Korsch, R.J., Williams, I.S., Foudoulis, Chris, 2004. Improved ${ }^{206} \mathrm{~Pb} /{ }^{238} \mathrm{U}$ microprobe geochronology by the monitoring of a trace-element-related matrix effect; SHRIMP, ID-TIMS, ELA-ICP-MS and oxygen isotope documentation for a series of zircon standards. Chem. Geol. $205,115-140$.

Cocherie, A., 1984. Interaction manteau-croûte: son rôle dans la genôse d'associations plutoniques calco-alcalines, contraintes géochimiques (éléments en traces et isotopes du strontium et de l'oxygéne). Thèse d'Etat Univ. Rennes I France, 246 pp. Doc. BRGM: 90 (1985).

Cocherie, A., Rossi, P., Le Bel, A., 1984. The Variscan calkalkalic plutonism of western Corsica: mineralogy and major and trace element geochemistry. Phys. Earth Planet. Inter. 35, 145-178.

Cocherie, A., Guerrot, C., Rossi, P., 1992. Single-zircon dating by step-wise Pb evaporation: comparison with other geochronological techniques applied to the Hercynian granites of Corsica, France. Chem. Geol., Isot. Geosci. Sect. $101,131-141$

Cocherie, A., Rossi, P., Fouillac, A.M., Vidal, P., 1994. Crust and mantle 
contributions to granite genesis—an example from the Variscan batholith of Corsica, France, studied by trace element and $\mathrm{Nd}-\mathrm{Sr}-\mathrm{O}$ isotope systematics. Chem. Geol. 115, 173-211.

Cocherie, A., Rossi, P., Fanning, C.M., Guerrot, C., 2005. Comparative use of TIMS and SHRIMP for U-Pb zircon dating and mafic tholeiitic layered complexes and dykes from the Corsican Batholith (France). Lithos 82, 185-219.

Corfu, F., Hanchar, J.M., Hoskin, P.W.O., Kinny, P., 2003. Atlas of zircon textures. Rev. Mineral. Geochem. 53, 469-500.

Corsini, M., Rolland, Y., 2009. Late evolution of the southern European Variscan belt: Exhumation of the lower crust in a context of oblique convergence. C.R. Geoscience 341, 214-223.

Cruciani, G., Franceschelli, M., Massonne, H.-J., Carosi, R., Montomoli, C., 2013. Pressure-temperature and deformational evolution of high-pressure metapelites from Variscan NE Sardinia, Italy. Lithos 175-176, 272-284.

Davies, J.H., von Blanckenburg, F., 1995. Slab breakoff: A model of lithosphere detachment and its test in the magmatism and deformation of collisional orogens. Earth Planet. Sci. Lett. 129, 85-102.

Durand-Delga, M., Rossi, P., 1991. Les massifs anciens de la France: la Corse. Sci. Géol. Mém. Strasbourg 44, 311-336.

Edel, J.-B., Montigny, R., Tuizat, R., 1981. Late Paleozoic rotations of Corsica and Sardinia: new evidence from paleomagnetic and $\mathrm{K}-\mathrm{Ar}$ studies. 
Tectonophysics 79, 201-203.

Elkins-Tanton, L.T., 2005. Continental magmatism caused by lithospheric delamination. In Foulger, G.L., Natland, J.H., Presnall, D.C., Anderson, D. L. (eds.), Plates, plumes, and paradigms. Geological Society of America Special Paper 388, p. 449-461.

Faure, M., Bé Mézème, E., Duguet, M., Cartier, C., Talbot, J.-Y., 2005. Paleozoic tectonic evolution of Medio-Europa from the example of the French Massif Central and Massif Armoricain. J. Virtual Explorer Electronic edition ISSN 1441-8142, 19 paper 5.

Faure, M., Bé Mézème, E., Cocherie, A., Rossi, P., Chemenda, A., Boutelier, D., 2008. Devonian geodynamic evolution of the Variscan Belt, insights from the French Massif Central and Massif Armoricain. Tectonics 27: TC2008, doi.org/10.1029/2007TC002115.

Faure, M., Sommers, C., Melleton, J., Cocherie, A., Lautout, O., 2009. The Léon Domain (French Massif Armoricain): a westward extension of the Mid-German Crystalline Rise? Structural and geochronological insights. Int. J. Earth Sci. 99, 65-81.

Faure, M., Cocherie, A., Bé-Mézème, E., Charles, N., Rossi, P., 2010. Middle Carboniferous crustal melting in the Variscan Belt: New insights from $\mathrm{U}-\mathrm{Th}-\mathrm{Pb}_{\text {tot. }}$ monazite and $\mathrm{U}-\mathrm{Pb}$ zircon ages of the Montagne Noire Axial Zone (southern French Massif Central). Gondwana Res. 18, 653-673.

Faure, M., Rossi, P., Gaché, J., Melleton, J., Frei, D., Li, X.H., Lin, W., 2014. 
Variscan orogeny in Corsica: New structural and geochronological insights, and its place in the Variscan geodynamic framework. Int. J. Earth Sci. in review.

Ferré, E.C., Leake, B.E., 2001. Geodynamic significance of early orogenic high-K crustal and mantle melts: example of the Corsica Batholith. Lithos 59, $47-67$.

Franceschelli, M., Puxeddu, G., Cruciani, G., Utzeri, D., 2007. Metabasites with eclogites facies relics from Variscides in Sardinia, Italy: a review. Int. J. Earth Sci. 96, 795-815

Franke, W., 1989. Variscan plate tectonics in Central Europe-current ideas and open questions. Tectonophysics 169, 221-228.

Giacomini, F., Dallai, L., Carminati, E., Tiepolo, M., Ghezzo, C., 2008. Exhumation of a Variscan orogenic complex: insights into the composite granulitic- amphibolitic metamorphic basement of south-east Corsica (France). J. Metamorph. Geol. 26, 403-436.

Janoušek V., Bowes D.R., Braithwaite C.J.R., Rogers G., 2000. Microstructural and mineralogical evidence for limited involvement of magma mixing in the petrogenesis of a Hercynian high-K calc-alkaline intrusion: the Kozárovice granodiorite, Central Bohemian Pluton, Czech Republic. Trans. Royal Soc. Edinburgh Earth Sci. 91,15-26.

Laporte, D., 1987. Un exemple d'intrusion syntectonique: l'intrusion d'lle-Rousse, Corse du NordOuest. Etude pétrographique, minéralogique et 
géochimique. Analyse structurale. Thése Doct. Univ. de St-Etienne, 422p.

Lardeaux, J.M., Menot, R.P., Orsini, J.B., Rossi, P., Naud, G., Libourel, G., 1994. Corsica and Sardinia in the Variscan chain. In: Keppie, J.D. (ed.), Pre-Mesozoic Geology in France and Related Areas. Springer-Verlag, Berlin, Germany, pp. 467-479.

Le Fort, P., 1975. Himalayas: The collided range. Present knowledge of the continental arc. Am. J. Sci. 275A, 1-44.

Le Fort, P., Cuney, M., Deniel, C., France-Lanord, C., Sheppard, S.M.F., Upreti, B.N., Vidal P., 1987. Crustal generation of the Himalayan leucogranites. Tectonophysics 134, 39-57.

Li, Q.L., Li, X.H., Liu, Y., Tang, G.Q., Yang, J.H., Zhu, W.G., 2010. Precise U-Pb and $\mathrm{Pb}-\mathrm{Pb}$ dating of Phanerozoic baddeleyite by SIMS with oxygen flooding technique. J. Analyt. Atom. Spectrom. 25, 1107-1113.

Li, X.H., Liu, Y., Li, Q.L., Guo, C.H., Chamberlain, K.R., 2009 Precise determination of Phanerozoic zircon $\mathrm{Pb} / \mathrm{Pb}$ age by multi-collector SIMS without external standardization. Geochem. Geophys. Geosyst. 10, Q04010. doi:10.1029/cGC002400.

Li, X.H., Tang, G.Q., Gong, B., Yang, Y.H., Hou, K.J., Hu, Z.C., Li, Q.L., Liu, Y., Li, W.X., 2013. Qinghu zircon: A working reference for microbeam analysis of $\mathrm{U}-\mathrm{Pb}$ age and $\mathrm{Hf}$ and $\mathrm{O}$ isotopes. Ch. Sci. Bull. 58, 4647-4654.

Libourel, G., 1985. Le complexe de Santa-Lucia-di-Mercurio (Corse). Ultramafites mantelliques, intrusion basique stratifiée, paragneiss 
granulitiques. Un équivalent possible des complexes de la zone d'Ivrée. PhD thesis Université Paul-Sabatier Toulouse 461 pp.

Ludwig, K.R., 2001. Users manual for Isoplot/Ex rev. 2.49, Spec. Publ. 1a, Berkeley Geochronol. Cent., Berkeley, California.

Maluski, H., 1976, ${ }^{40} \mathrm{Ar}-{ }^{39} \mathrm{Ar}$ ages of biotites from Corsica and arguments for Permian age of alkaline granitic intrusion. Contrib. Mineral. Petrol. 58, 305-317.

Ménot, R.-P., Orsini, J.-B., 1990. Evolution du socle anté-stéphanien de Corse: événements magmatiques et métamorphiques. Schweiz Minera.I Petrogr. Mitt. 70, 35-53

Orsini, J.B., Cocirta, C., Zorpi, M.J., 1991. Genesis of mafic microgranular enclaves through differentiation of basic magmas, mingling and chemical exchanges with their host granitoid magmas. In: Didier, J., Barbarin, B. (Eds.), Enclaves and Granite Petrology. Elsevier, Amsterdam, The Netherlands, pp. 445-464.

Palagi, P., Laporte, D., Lardeaux, J.-M., Menot, R.-P., Orsini, J.-B., 1985. Identification d'un complexe leptyno-amphibolique au sein des « gneiss de Belgodère» (Corse occidentale). C.R. Acad. Sci. Paris Ser II 301: 1047-1052.

Paquette, J.L., Ménot, R.P., Pin, C., Orsini, J.B., 2003. Episodic and short-lived granitic pulses in a post-collisional setting: evidence from precise $\mathrm{U}-\mathrm{Pb}$ zircon dating through a crustal cross-section in Corsica. Chem. Geol. 198, 
$1-20$.

Poitrasson, F., Pin, C., Duthou, J.L., Platevoet, B., 1994, Aluminous subsolvus anorogenic granite genesis in the light of $\mathrm{Nd}$ isotopic heterogeneity. Chem Geol 112,199-219.

Poitrasson, F., Duthou, J.L., Pin, C., 1995. The relationship between petrology and $\mathrm{Nd}$ isotopes as evidence for contrasting anorogenic granite genesis: example of the Corsican Province (SE France). J. Petrol. 36,1251-1274.

Poitrasson. F., Paquette, J.-L., Montel, J.-M., Pin, C., Duthou, J.-L., 1998. Importance of late-magmatic and hydrothermal fluids on the Sm-Nd isotope mineral systematics of hypersolvus granites. Chem. Geol. 146, 187-203.

Renna, M.R., Tribuzio, R., Tiepolo, M., 2007. Origin and timing of the post-Variscan gabbro-granite complex of Porto (Western Corsica). Contrib. Mineral. Petrol. 154, 493-517.

Rolland, Y., Corsini, M., Demoux, A., 2009. Metamorphic and structural evolution of the Maures-Tanneron massif (SE Variscan chain): evidence of doming along a transpressional margin. Bull. Soc. géol. Fr., 180, 217-230.

Rossi, P., Cocherie, A., 1991. Genesis of a Variscan batholith: field, mineralogical and geochemical evidence from the Corsica-Sardinia batholith Tectonophysics 195, 319-346.

Rossi, P., Cocherie, A., 1995. Chronologie des intrusions du batholite corse: données de l'évaporation du plomb sur monozircon. Magmatismes dans le Sud-Est de la France. Séance Spécialisée de la Société Géologique de 
France, Université de Nice, France, 24 pp.

Rossi, P., Calvez, J.Y., Cocherie, A., 1988. Age varisque précoce du plutonisme magnésio-potassique en Corse occidentale: conséquences géodynamiques. C.R. Acad. Sci. Paris 207, 1541-1547.

Rossi, P., Durand Delga, M., Cocherie, A., 1993. Caractère volcano-plutonique du magmatisme calco-alcalin composite d'âge stéphanien supérieurpermien inférieur en Corse. C.R. Acad. Sci. Paris 316, 1779-1788.

Rossi, P., Durand-Delga, M., Cocherie, A., 1995. Identification en Corse d'un socle panafricain (cadomien), conséquences sur la paléogéographie de l'orogène varisque sud-européen. C.R. Acad. Sci. Paris 321 II, 983-999.

Rossi, P., Durand-Delga, M., Lahondère, J.-C., Lahondère, D., 2001. Carte géologique de la France au 1/50000. Carte et Notice explicative de la feuille Santo-Pietro-di-Tenda 224pp BRGM, Orléans, France.

Rossi, P., Cocherie, A., Fanning, M., Guerrot, C., 2005. Comparative use of TIMS and SHRIMP for U-Pb zircon dating of A-type granites and mafic tholeiitic layered complexes and dykes from the Corsican batholith (France). Lithos 82, 185-219.

Rossi, P., Oggiano, G., Cocherie, A., 2009. A restored section of the "southern Variscan realm" across the Corsica-Sardinia microcontinent. C.R. Geoscience 341, 224-238.

Rouire, J., Bourges, F., Rossi, P., Libourel, G., 1993. Carte géol. France (1/50 000), Carte et Notice explicative de la feuille Porto-Vecchio. Orléans BRGM 
$61 \mathrm{p}$.

Schaltegger, U., Corfu, F., 1992. The age and source of late Hercynian magmatism in the central Alps: evidence from precise $\mathrm{U}-\mathrm{Pb}$ ages and initial Hf isotopes. Contrib. Mineral. Petrol. 111, 329-344.

Stacey, J.S., Kramers, J.D., 1975. Approximation of terrestrial lead isotope evolution by a two-stage model. Earth Planet. Sci. Lett. 26, 207-221.

Tabaud, A.S., 2012. Le magmatisme des Vosges: conséquence des subductions paléozoïques (datation, pétrologie, géochimie, ASM). Thèse Doct Univ Strasbourg $223 p$

Wiedenbeck, M., Alle, P., Corfu, F., Griffin, W.L., Meier, M., Oberli, F., Vonquadt, A., Roddick, J.C., Speigel, W., 1995. Three natural zircon standards for U-Th-Pb, Lu-Hf, trace-element and REE analyses. Geostand. Newslett. 19, $1-23$. 


\section{Figure captions}

Fig. 1 Geological sketch map of Corsica (modified after Ferré and Leake, 2001; Paquette et al., 2003). The red dots indicate the localities sample, with sample numbers shown nearby. S1 and S2 are the possible Variscan sutures proposed by Faure et al. (in review).

Fig. 2 Cathodoluminescence images for representative zircons for SIMS U-Pb dating. Red ellipses indicate the analytical spots (with ages shown nearby). SIMS spots are $30 \mu \mathrm{m}$ in length for scale.

Fig. 3 SIMS zircon U-Pb concordia age plots for migmatite 11CO21 (a) from the Fautea metamorphic complex; migmatite 11C094A (b) and migmatite $11 \mathrm{CO} 4 \mathrm{C}$ (c) from the Vignola metamorphic complex; migmatite $11 \mathrm{CO} 67$ (d) from the Belgodère metamorphic complex, and Belgodère "orthogneiss" or magmatically foliated granite 11CO66(e) that intruded into the migmatite. MSWD* $=$ MSWD of concordance.

Fig. 4 SIMS zircon U-Pb concordia age plots for quartz monzonite samples $11 \mathrm{CO} 57$ (a), 11CO58 (b), and 11CO60 (c), monzogranite sample 12FR34 (d), and monzogabbro enclave sample 11CO59 (e) from the Calvi-Ile Rousse high Mg-K intrusions of U1 suite. MSWD* = MSWD of concordance.

Fig. 5 Probabilistic histogram of LA-ICPMS zircon ${ }^{206} \mathrm{~Pb} /{ }^{238} \mathrm{U}$ age distributions $(<380-\mathrm{Ma})$ for two felsic granulite samples ( $\mathrm{C} 1$ and $\mathrm{C} 6)$ from Fautea. Data are from Giacomini et al. (2008). 
Fig. 6 Interpretative crustal-scale cross-section of Variscan Corsica (adapted from Faure et al., 2014). Two suture zones S1 and S2 bounding the Argentella Proterozoic block, to the SW, and NE, respectively are recognized. Contemporaneous migmatites, dated at ca. $345 \mathrm{Ma}$ develop both in the Western and Eastern domains. The high Mg-K intrusions emplace at ca. 330Ma. A slab break-off model might account for the formation of migmatites and high $\mathrm{Mg}-\mathrm{K}$ plutons (see text for discussion on these possible geodynamic mechanisms).

Fig. 7 Simplified geodynamic model for the Variscan collisional orogeny in Corsica. See text for discussion on mechanisms accounting for migmatization by crustal anatexis at ca. $345 \mathrm{Ma}$ and $\mathrm{Mg}-\mathrm{K}$ magmatism at ca. $330 \mathrm{Ma}$. 
A. Pre-360 Ma, continental subduction and related high pressure metamorphism

SW

Western metamorphic domain (Zicavo)

\section{Argentella Proterozoic Block Eastern domain (Tenda)}

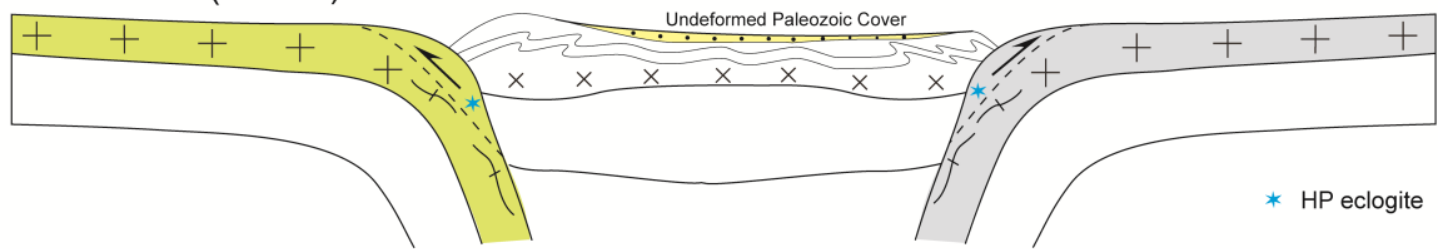

B. Ca. $360 \mathrm{Ma}$,tearing of subducted slab related HP-HT granulite facies metamorphism SW $\mathrm{S}_{2}$ Suture Undeformed Paleozoic Cover $\quad \mathrm{S}_{1}$ Suture

NE

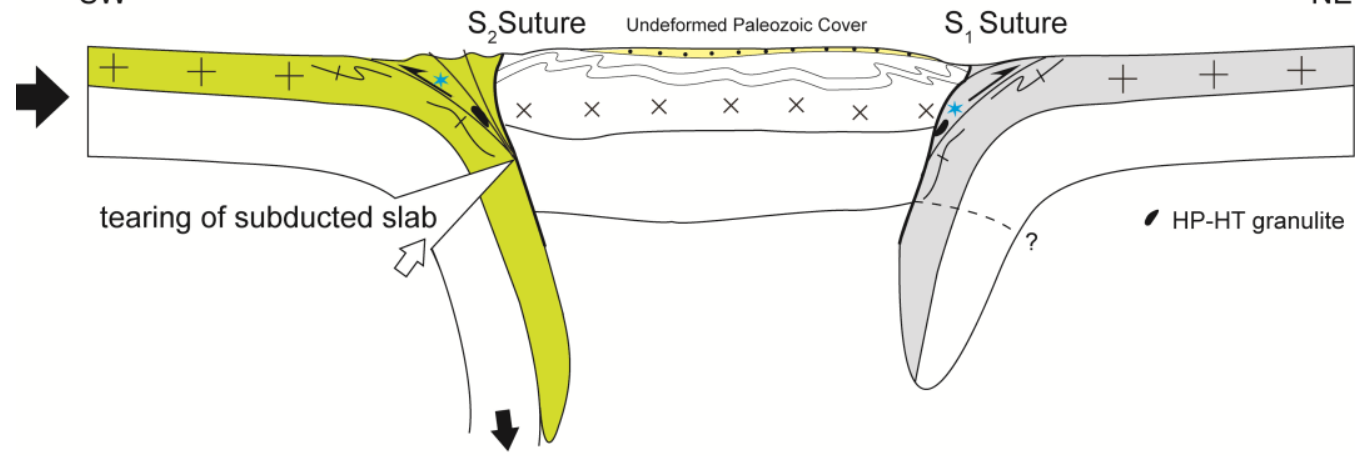

C. Ca. $345 \mathrm{Ma}$, exhumation and anatexis of subducted crust under amphibolite-facies metamorphism

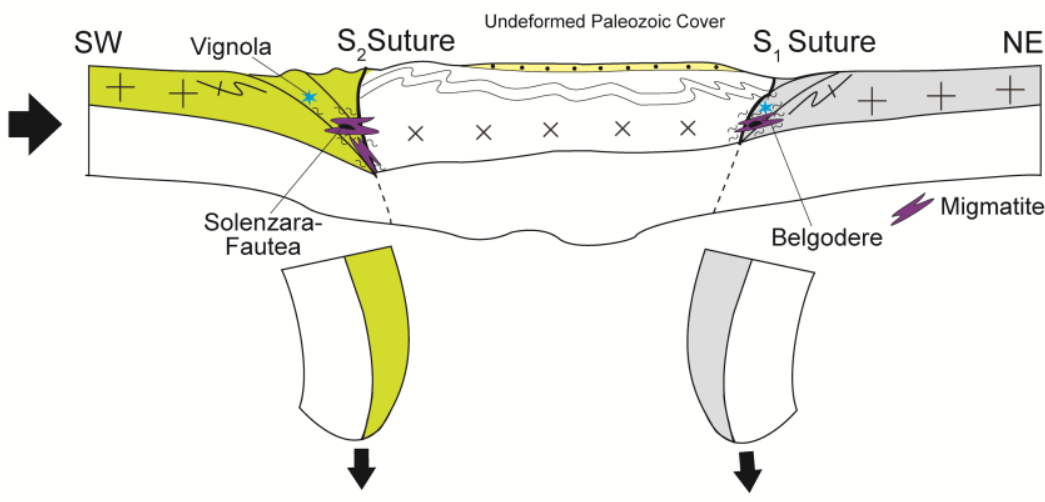

D. Ca. $330 \mathrm{Ma}$, mantle melting and generation of $\mathrm{Mg}-\mathrm{K}$ magmatism $\left(\mathrm{U}_{1}\right.$ series )

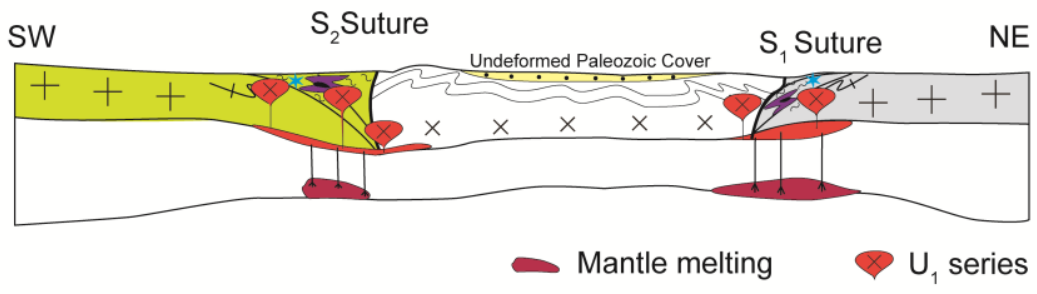




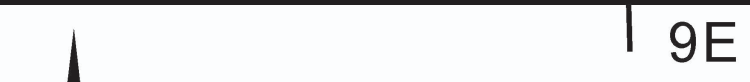

$42 N$
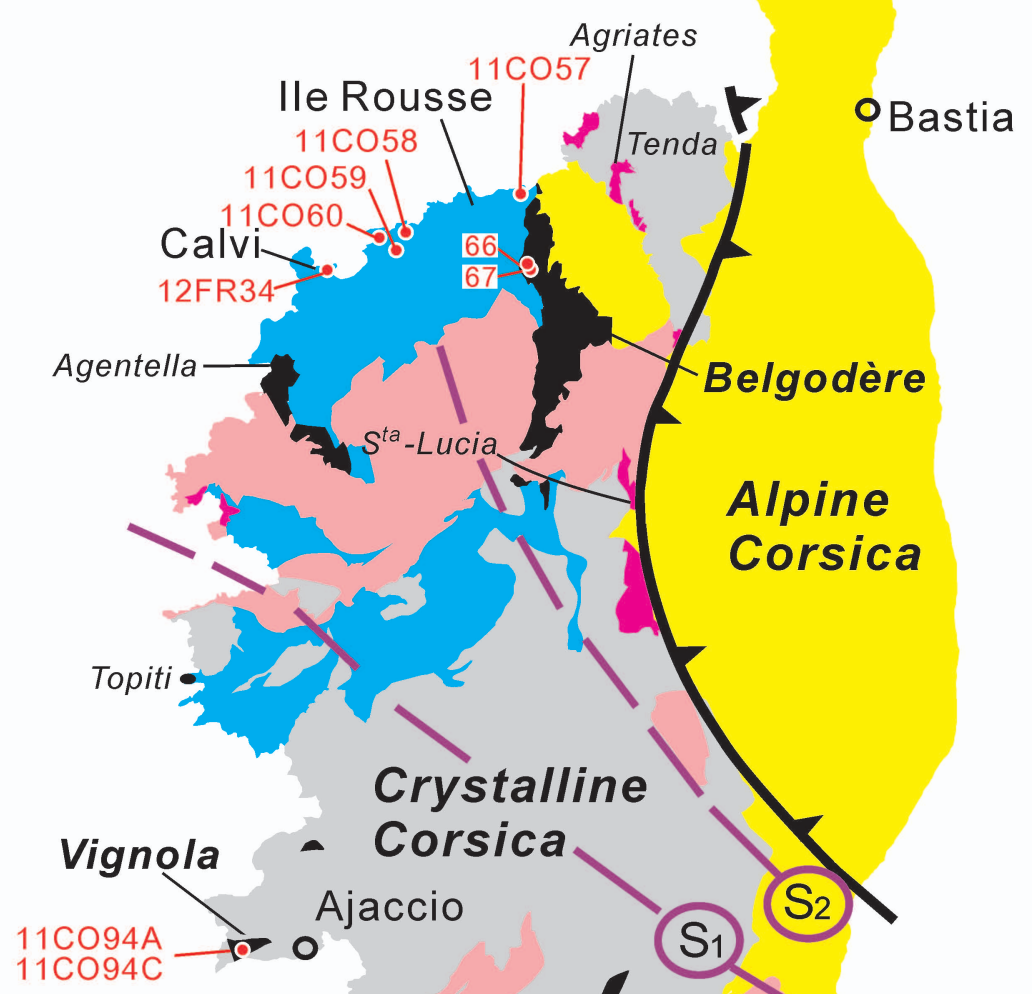

Cenozoic and

Mesozoic Formations

U3 Alkaline intrusives and volcanics

U2 Calc-alkaline intrusives

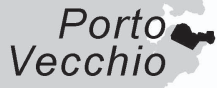

U1 high Mg-K

intrusives

Variscan metamorphic rocks 
11C021@9

11C094A@8

$350 \mathrm{Ma}$

11C021@19

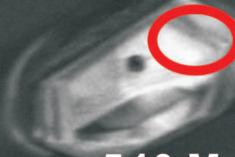

$540 \mathrm{Ma}$

11C067@24

$227 \mathrm{Ma}$

11C058@8

$328 \mathrm{Ma}$

11C021@16

$2099 \mathrm{Ma}$

11C066@16

$336 \mathrm{Ma}$

$=$

$329 \mathrm{Ma}$
11C094C@16

$341 \mathrm{Ma}$

$344 \mathrm{Ma}$

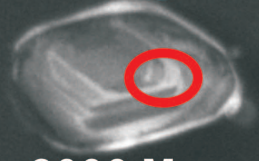

11C060@16

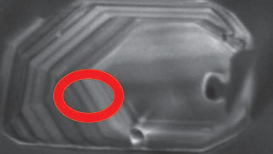

$187 \mathrm{Ma}$

11C059@4

11C094C@14c

$1938 \mathrm{Ma}$

11C066@4

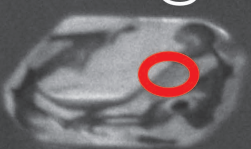

$328 \mathrm{Ma}$
11C067@2

$341 \mathrm{Ma}$

11C067@10

$620 \mathrm{Ma}$

11C057@13

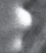

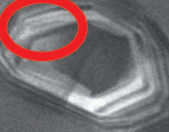

$331 \mathrm{Ma}$

12FR34@18

334 Ma 

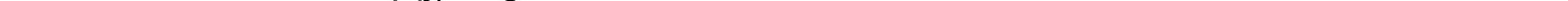
Metamorphic zircons from

Felsic granulites (C1 and C6)

8 from Fautea-Solenzaraa

(Giacomini et al., 2008) 
Western metamorphic domain(ZicavoSolenzara-FauteaTopiti-Vignola)

Argentella Proterozoic Block
$\mathrm{S}_{2}$

Belgodere Eastern domain metamorphic (Tenda-Agriates) unit

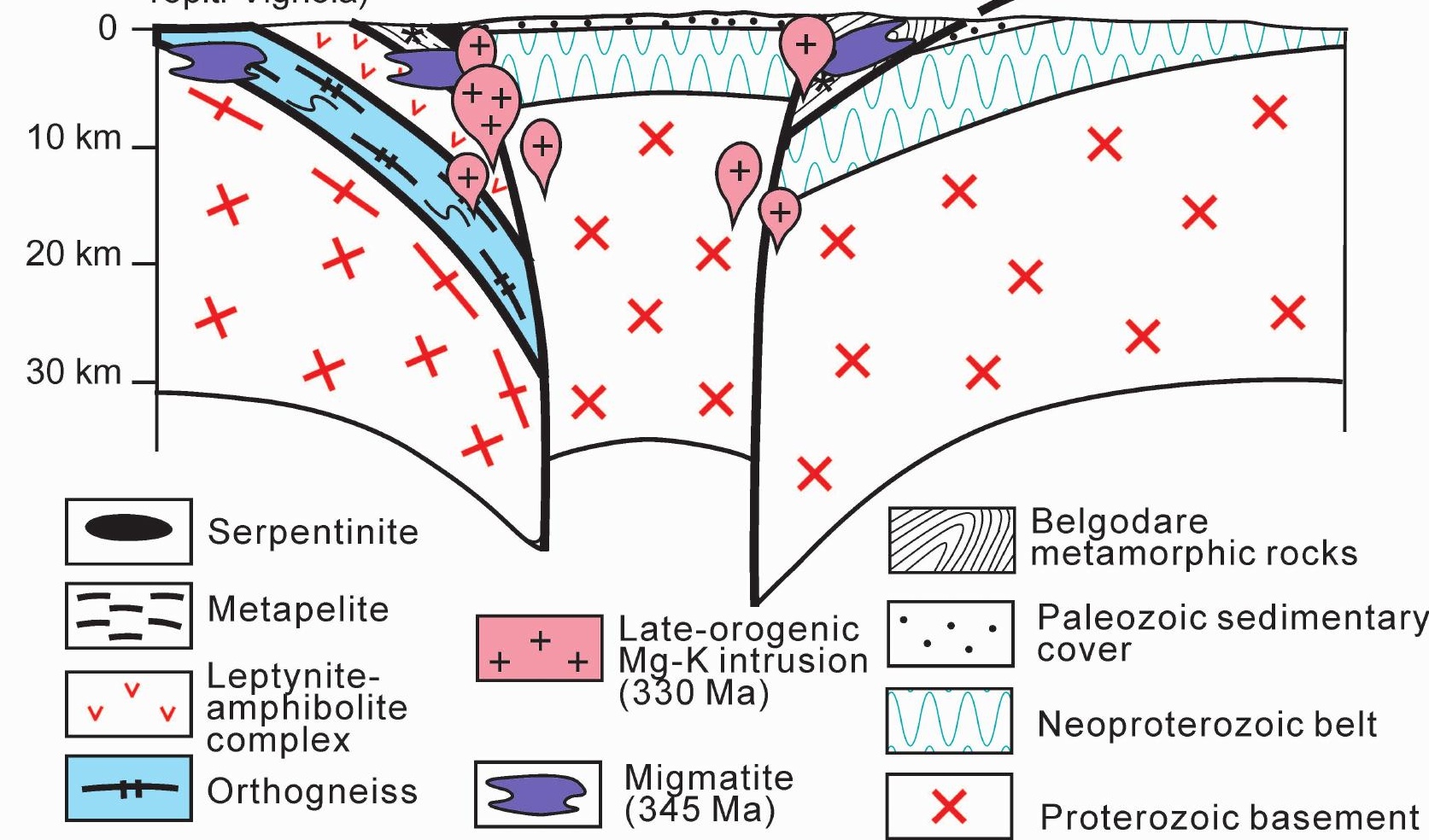


Appendix Table 1 SIMS U-Pb zircon data forVariscan migmatite

\begin{tabular}{|c|c|c|c|c|c|c|c|c|c|c|c|c|c|c|}
\hline \multirow[b]{2}{*}{$\begin{array}{l}\text { Sample/ } \\
\text { spot \# }\end{array}$} & \multirow[b]{2}{*}{$\begin{array}{c}{[\mathrm{U}]} \\
\mathrm{ppm}\end{array}$} & \multirow[b]{2}{*}{$\begin{array}{l}{[\mathrm{Th}]} \\
\mathrm{ppm}\end{array}$} & \multirow[b]{2}{*}{$\mathrm{Th} / \mathrm{U}$} & \multirow[b]{2}{*}{$\mathbf{f}_{206} \%$} & \multicolumn{4}{|c|}{ Radiogenic isotopic ratios } & \multirow[b]{2}{*}{${ }^{207} \underline{\mathrm{Pb}}$} & \multirow[b]{2}{*}{$\begin{array}{l} \pm \sigma \\
\%\end{array}$} & \multicolumn{4}{|c|}{ Isotopic ages (Ma) } \\
\hline & & & & & ${ }^{207} \frac{\mathrm{Pb}}{\mathrm{235}}$ & $\begin{array}{l} \pm \sigma \\
\%\end{array}$ & ${ }^{206} \underline{\mathrm{Pb}}$ & $\begin{array}{l} \pm \sigma \\
\%\end{array}$ & & & ${ }^{207} \underline{\mathrm{Pb}}$ & $\pm \sigma$ & ${ }^{206} \underline{\mathrm{Pb}}$ & $\pm \sigma$ \\
\hline 11CO-21@10 & 999 & 17 & 0,02 & 0,02 & 0,396 & 1,69 & 0,0537 & 1,52 & 0,0535 & 0,75 & 338,9 & 4,9 & 337,5 & 5,0 \\
\hline 11CO-21@7 & 409 & 32 & 0,08 & 0,73 & 0,393 & 3,23 & 0,0541 & 1,50 & 0,0527 & 2,86 & 336,9 & 9,3 & 339,6 & 5,0 \\
\hline 11CO-21@4 & 435 & 20 & 0,05 & 0,14 & 0,406 & 2,01 & 0,0546 & 1,50 & 0,0540 & 1,34 & 346,0 & 5,9 & 342,5 & 5,0 \\
\hline 11CO-21@12 & 477 & 42 & 0,09 & 0,04 & 0,399 & 1,86 & 0,0546 & 1,50 & 0,0530 & 1,09 & 341,1 & 5,4 & 342,7 & 5,0 \\
\hline 11CO-21@5 & 407 & 31 & 0,08 & 0,01 & 0,415 & 2,17 & 0,0547 & 1,50 & 0,0551 & 1,57 & 352,7 & 6,5 & 343,1 & 5,0 \\
\hline 11C0-21@13 & 506 & 15 & 0,03 & 0,01 & 0,407 & 1,89 & 0,0553 & 1,51 & 0,0534 & 1,14 & 346,5 & 5,6 & 346,8 & 5,1 \\
\hline 11CO-21@1 & 404 & 37 & 0,09 & 0,07 & 0,408 & 1,92 & 0,0557 & 1,50 & 0,0532 & 1,20 & 347,7 & 5,7 & 349,1 & 5,1 \\
\hline 11Co-21@9 & 766 & 10 & 0,01 & 0,30 & 0,413 & 1,83 & 0,0557 & 1,50 & 0,0538 & 1,05 & 351,4 & 5,5 & 349,7 & 5,1 \\
\hline 11CO-21@15 & 779 & 22 & 0,03 & 0,02 & 0,415 & 1,77 & 0,0561 & 1,50 & 0,0537 & 0,94 & 352,5 & 5,3 & 351,7 & 5,1 \\
\hline 11CO-21@20 & 310 & 107 & 0,35 & 0,03 & 0,547 & 2,45 & 0,0696 & 1,53 & 0,0570 & 1,91 & 443,0 & 8,8 & 433,5 & 6,4 \\
\hline 11CO-21@14 & 579 & 120 & 0,21 & 0,14 & 0,614 & 1,87 & 0,0781 & 1,53 & 0,0570 & 1,07 & 486,4 & 7,2 & 484,9 & 7,2 \\
\hline 11CO-21@3 & 350 & 227 & 0,65 & 0,04 & 0,674 & 2,23 & 0,0841 & 1,61 & 0,0582 & 1,55 & 523,4 & 9,2 & 520,5 & 8,1 \\
\hline 11CO-21@17 & 97 & 61 & 0,63 & 0,22 & 0,669 & 2,68 & 0,0865 & 1,68 & 0,0561 & 2,09 & 520,2 & 11,0 & 534,9 & 8,6 \\
\hline 11CO-21@19 & 136 & 159 & 1,17 & 0,06 & 0,740 & 2,03 & 0,0874 & 1,51 & 0,0614 & 1,35 & 562,6 & 8,8 & 540,1 & 7,8 \\
\hline 11CO-21@8 & 414 & 283 & 0,68 & 0,04 & 0,821 & 1,73 & 0,0983 & 1,52 & 0,0606 & 0,83 & 608,8 & 8,0 & 604,6 & 8,8 \\
\hline 11C0-21@18 & 181 & 116 & 0,64 & 0,01 & 0,877 & 1,93 & 0,1007 & 1,54 & 0,0632 & 1,18 & 639,4 & 9,2 & 618,5 & 9,1 \\
\hline 11CO-21@6 & 396 & 139 & 0,35 & 0,04 & 0,874 & 1,81 & 0,1027 & 1,61 & 0,0618 & 0,82 & 637,9 & 8,6 & 630,1 & 9,7 \\
\hline 11Co-21@16 & 562 & 184 & 0,33 & 0,01 & 5,730 & 1,61 & 0,3195 & 1,57 & 0,1301 & 0,32 & 1935,9 & 14,0 & 1787,3 & 24,6 \\
\hline 11CO-94A@20 & 11514 & 144 & 0,01 & 0,18 & 0,21763 & 2,66 & 0,0303 & 1,54 & 0,0520 & 2,17 & 199,9 & 4,8 & 192,6 & 3 \\
\hline 11C0-94A@12 & 7683 & 613 & 0,08 & 1,37 & 0,31479 & 2,18 & 0,0426 & 1,57 & 0,0536 & 1,51 & 277,9 & 5,3 & 268,8 & 4 \\
\hline 11CO-94A@19 & 3694 & 265 & 0,07 & 0,93 & 0,36225 & 1,99 & 0,0491 & 1,57 & 0,0536 & 1,23 & 313,9 & 5,4 & 308,7 & 5 \\
\hline 11C0-94A@17 & 2617 & 142 & 0,05 & 0,20 & 0,38434 & 1,60 & 0,0518 & 1,50 & 0,0539 & 0,54 & 330,2 & 4,5 & 325,3 & 5 \\
\hline 11C0-94A@11 & 2934 & 119 & 0,04 & 0,22 & 0,38664 & 1,59 & 0,0527 & 1,50 & 0,0532 & 0,53 & 331,9 & 4,5 & 331,1 & 5 \\
\hline 11C0-94A@14 & 3449 & 98 & 0,03 & 0,46 & 0,39901 & 1,69 & 0,0537 & 1,50 & 0,0539 & 0,77 & 340,9 & 4,9 & 337,0 & 5 \\
\hline 11C0-94A@6 & 2428 & 169 & 0,07 & 0,04 & 0,39569 & 1,58 & 0,0538 & 1,50 & 0,0534 & 0,49 & 338,5 & 4,6 & 337,7 & 5 \\
\hline 11CO-94A@16 & 2248 & 76 & 0,03 & 0,03 & 0,40060 & 1,68 & 0,0542 & 1,50 & 0,0536 & 0,74 & 342,1 & 4,9 & 340,5 & 5 \\
\hline 11CO-94A@8 & 2466 & 152 & 0,06 & 0,10 & 0,39964 & 1,60 & 0,0543 & 1,50 & 0,0533 & 0,56 & 341,4 & 4,7 & 341,1 & 5 \\
\hline 11CO-94A@2 & 1938 & 555 & 0,29 & 1,15 & 0,40134 & 1,85 & 0,0548 & 1,50 & 0,0531 & 1,07 & 342,6 & 5,4 & 344,0 & 5 \\
\hline 11C0-94A@7 & 2304 & 131 & 0,06 & 0,20 & 0,40242 & 1,60 & 0,0551 & 1,50 & 0,0530 & 0,56 & 343,4 & 4,7 & 345,8 & 5 \\
\hline 11CO-94A@4 & 881 & 124 & 0,14 & 0,01 & 0,40870 & 1,80 & 0,0551 & 1,50 & 0,0538 & 1,00 & 347,9 & 5,3 & 345,8 & 5 \\
\hline 11CO-94A@13 & 8724 & 376 & 0,04 & 0,86 & 0,40933 & 1,94 & 0,0553 & 1,52 & 0,0537 & 1,20 & 348,4 & 5,7 & 347,0 & 5 \\
\hline 11CO-94A@10 & 1131 & 124 & 0,11 & 0,02 & 0,40425 & 1,74 & 0,0555 & 1,51 & 0,0528 & 0,85 & 344,7 & 5,1 & 348,2 & 5 \\
\hline 11CO-94A@18 & 1127 & 218 & 0,19 & 0,01 & 0,40699 & 1,78 & 0,0555 & 1,50 & 0,0531 & 0,96 & 346,7 & 5,3 & 348,4 & 5 \\
\hline 11CO-94A@5 & 432 & 63 & 0,15 & 0,01 & 0,41247 & 1,86 & 0,0560 & 1,50 & 0,0534 & 1,10 & 350,6 & 5,5 & 351,2 & 5 \\
\hline 11CO-94A@15 & 5642 & 451 & 0,08 & 0,35 & 0,41724 & 1,71 & 0,0570 & 1,50 & 0,0531 & 0,82 & 354,1 & 5,1 & 357,5 & 5 \\
\hline
\end{tabular}




\begin{tabular}{|c|c|c|c|c|c|c|c|c|c|c|c|c|c|}
\hline 11Co-94C@4 & 3685 & 223 & 0,06 & 0,03 & 0,398 & 1,56 & 0,0541 & 1,50 & 0,0533 & 0,40 & 340,0 & 4,5 & 339,7 \\
\hline 11CO-94C@1 & 648 & 99 & 0,15 & 1,58 & 0,400 & 2,53 & 0,0541 & 1,51 & 0,0536 & 2,02 & 329,9 & 7,1 & 339,8 \\
\hline 11CO-94C@16 & 2442 & 493 & 0,20 & 0,20 & 0,404 & 1,69 & 0,0548 & 1,51 & 0,0535 & 0,75 & 344,6 & 4,9 & 343,7 \\
\hline 11CO-94C@8 & 1600 & 586 & 0,37 & 0,46 & 0,406 & 1,99 & 0,0552 & 1,50 & 0,0533 & 1,30 & 345,6 & 5,8 & 346,5 \\
\hline 11CO-94C@3 & 840 & 411 & 0,49 & 0,54 & 0,404 & 2,03 & 0,0553 & 1,51 & 0,0529 & 1,38 & 344,5 & 6,0 & 347,2 \\
\hline 11Co-94C@17 & 2476 & 395 & 0,16 & 0,76 & 0,406 & 2,01 & 0,0554 & 1,50 & 0,0531 & 1,34 & 345,7 & 5,9 & 347,4 \\
\hline 11Co-94C@2 & 2305 & 593 & 0,26 & 0,01 & 0,411 & 1,70 & 0,0555 & 1,51 & 0,0538 & 0,78 & 349,8 & 5,0 & 348,1 \\
\hline 11Co-94C@11 & 4852 & 588 & 0,12 & 0,05 & 0,411 & 1,55 & 0,0555 & 1,51 & 0,0536 & 0,36 & 349,3 & 4,6 & 348,3 \\
\hline 11Co-94C@6 & 2551 & 539 & 0,21 & 0,02 & 0,407 & 1,57 & 0,0556 & 1,50 & 0,0531 & 0,46 & 346,7 & 4,6 & 348,9 \\
\hline 11Co-94C@14r & 1112 & 89 & 0,08 & 0,39 & 0,874 & 2,03 & 0,0817 & 1,79 & 0,0776 & 0,95 & 637,8 & 9,7 & 506,1 \\
\hline 11Co-94C@19 & 895 & 40 & 0,04 & 0,06 & 0,747 & 1,81 & 0,0863 & 1,55 & 0,0627 & 0,94 & 566,3 & 7,9 & 533,7 \\
\hline 11Co-94C@12 & 200 & 49 & 0,24 & 0,01 & 0,759 & 2,11 & 0,0926 & 1,55 & 0,0595 & 1,44 & 573,5 & 9,3 & 570,6 \\
\hline 11Co-94C@10 & 297 & 66 & 0,22 & 0,07 & 0,744 & 1,83 & 0,0927 & 1,50 & 0,0582 & 1,05 & 564,5 & 8,0 & 571,7 \\
\hline 11C0-94C@13 & 3031 & 383 & 0,13 & 0,08 & 0,751 & 1,56 & 0,0928 & 1,51 & 0,0587 & 0,39 & 568,8 & 6,8 & 572,0 \\
\hline 11Co-94C@21 & 324 & 113 & 0,35 & 0,03 & 0,758 & 1,78 & 0,0944 & 1,50 & 0,0582 & 0,97 & 572,8 & 7,8 & 581,4 \\
\hline 11C0-94C@9 & 645 & 157 & 0,24 & 0,03 & 0,753 & 1,88 & 0,0944 & 1,51 & 0,0578 & 1,13 & 570,0 & 8,2 & 581,7 \\
\hline 11C0-94C@7 & 200 & 100 & 0,50 & 0,01 & 0,785 & 1,97 & 0,0966 & 1,50 & 0,0590 & 1,28 & 588,5 & 8,8 & 594,5 \\
\hline 11Co-94C@18 & 265 & 116 & 0,44 & 0,02 & 0,830 & 1,80 & 0,1007 & 1,51 & 0,0598 & 0,99 & 613,7 & 8,3 & 618,3 \\
\hline 11C0-94C@14c & 319 & 105 & 0,33 & 0,03 & 5,277 & 1,55 & 0,3222 & 1,50 & 0,1188 & 0,38 & 1865,1 & 13,3 & 1800,6 \\
\hline 11CO-67@17 & 4904 & 137 & 0,03 & 0,56 & 0,129 & 3,31 & 0,0179 & 3,19 & 0,0523 & 0,88 & 123,6 & 3,9 & 114,6 \\
\hline 11CO-67@9 & 4027 & 509 & 0,13 & 0,16 & 0,172 & 1,75 & 0,0239 & 1,55 & 0,0524 & 0,82 & 161,6 & 2,6 & 153,7 \\
\hline 11CO-67@24 & 2810 & 75 & 0,03 & 0,09 & 0,260 & 1,64 & 0,0359 & 1,54 & 0,0525 & 0,57 & 234,7 & 3,4 & 227,4 \\
\hline 11CO-67@23 & 2560 & 192 & 0,07 & 0,83 & 0,299 & 1,65 & 0,0402 & 1,57 & 0,0524 & 1,02 & 265,2 & 6,1 & 254,1 \\
\hline 11Co-67@11 & 2446 & 104 & 0,04 & 0,09 & 0,336 & 1,68 & 0,0457 & 1,50 & 0,0533 & 0,76 & 294,0 & 4,3 & 287,8 \\
\hline 11Co-67@15 & 2815 & 1151 & 0,41 & 0,08 & 0,348 & 1,60 & 0,0478 & 1,51 & 0,0534 & 0,53 & 303,1 & 4,2 & 301,2 \\
\hline 11Co-67@16 & 1025 & 154 & 0,15 & 0,41 & 0,364 & 1,84 & 0,0497 & 1,50 & 0,0532 & 1,06 & 315,4 & 5,0 & 312,5 \\
\hline 11Co-67@14 & 758 & 124 & 0,16 & 0,16 & 0,380 & 1,93 & 0,0516 & 1,50 & 0,0534 & 1,21 & 326,9 & 5,4 & 324,1 \\
\hline 11Co-67@18 & 859 & 92 & 0,11 & 0,10 & 0,383 & 1,82 & 0,0523 & 1,60 & 0,0531 & 0,87 & 329,4 & 5,1 & 328,9 \\
\hline 11CO-67@19 & 686 & 617 & 0,90 & 0,08 & 0,386 & 1,78 & 0,0525 & 1,51 & 0,0533 & 0,96 & 331,2 & 5,1 & 329,7 \\
\hline 11Co-67@5 & 1515 & 96 & 0,06 & 0,09 & 0,391 & 1,70 & 0,0531 & 1,53 & 0,0533 & 0,73 & 334,8 & 4,9 & 333,7 \\
\hline 11Co-67@20 & 854 & 116 & 0,14 & 0,02 & 0,392 & 1,71 & 0,0533 & 1,51 & 0,0533 & 0,81 & 330,2 & 4,8 & 334,6 \\
\hline 11Co-67@8 & 1016 & 49 & 0,05 & 0,02 & 0,396 & 1,81 & 0,0538 & 1,50 & 0,0534 & 1,01 & 338,8 & 5,2 & 338,0 \\
\hline 11Co-67@4 & 823 & 58 & 0,07 & 0,01 & 0,396 & 1,84 & 0,0540 & 1,50 & 0,0531 & 1,07 & 338,4 & 5,3 & 339,1 \\
\hline 11Co-67@2 & 387 & 211 & 0,54 & 0,03 & 0,402 & 1,86 & 0,0543 & 1,50 & 0,0536 & 1,10 & 337,4 & 5,4 & 340,9 \\
\hline 11CO-67@12 & 1002 & 222 & 0,22 & 0,03 & 0,414 & 1,72 & 0,0557 & 1,55 & 0,0539 & 0,75 & 352,0 & 5,1 & 354,2 \\
\hline 11CO-67@6 & 835 & 30 & 0,04 & 0,04 & 0,620 & 1,84 & 0,0786 & 1,58 & 0,0572 & 0,94 & 478,8 & 7,0 & 488,0 \\
\hline 11CO-67@1 & 641 & 63 & 0,10 & 0,03 & 0,630 & 1,69 & 0,0802 & 1,50 & 0,0570 & 0,78 & 487,5 & 6,6 & 497,3 \\
\hline 11Co-67@13 & 467 & 259 & 0,55 & 0,15 & 0,661 & 1,78 & 0,0834 & 1,50 & 0,0574 & 0,95 & 515,0 & 7,2 & 516,6 \\
\hline 11Co-67@3 & 651 & 284 & 0,44 & 0,02 & 0,751 & 1,80 & 0,0914 & 1,53 & 0,0596 & 0,95 & 568,8 & 7,9 & 563,8 \\
\hline 11Co-67@7 & 315 & 149 & 0,47 & 0,05 & 0,762 & 1,81 & 0,0930 & 1,51 & 0,0594 & 0,99 & 574,9 & 8,0 & 573,1 \\
\hline 11CO-67@10 & 1155 & 157 & 0,14 & 0,02 & 0,849 & 1,66 & 0,1009 & 1,50 & 0,0611 & 0,72 & 624,1 & 7,8 & 619,5 \\
\hline
\end{tabular}




\begin{tabular}{|c|c|c|c|c|c|c|c|c|c|c|c|c|c|c|}
\hline 11CO-66@19 & 4613 & 692 & 0,15 & 1,90 & 0,128 & 2,91 & 0,0187 & 1,72 & 0,0496 & 2,34 & 122,0 & 3,3 & 119,4 & 2,0 \\
\hline 11Co-66@25 & 2870 & 1172 & 0,41 & 2,69 & 0,159 & 3,71 & 0,0225 & 1,97 & 0,0512 & 3,14 & 150,1 & 5,2 & 143,7 & 2,8 \\
\hline 11Co-66@9 & 4405 & 883 & 0,20 & 0,50 & 0,172 & 2,00 & 0,0242 & 1,80 & 0,0516 & 0,88 & 161,6 & 3,0 & 154,4 & 2,7 \\
\hline 11Co-66@6 & 4385 & 590 & 0,13 & 0,76 & 0,193 & 1,95 & 0,0270 & 1,56 & 0,0517 & 1,16 & 179,0 & 3,2 & 172,0 & 2,7 \\
\hline 11CO-66@4 & 2780 & 1339 & 0,48 & 0,63 & 0,210 & 4,20 & 0,0293 & 4,03 & 0,0519 & 1,19 & 193,6 & 7,4 & 186,5 & 7,4 \\
\hline 11Co-66@3 & 3909 & 373 & 0,10 & 2,22 & 0,215 & 2,53 & 0,0299 & 1,52 & 0,0521 & 2,02 & 197,7 & 4,6 & 190,0 & 2,8 \\
\hline 11CO-66@13 & 2723 & 273 & 0,10 & 1,03 & 0,244 & 2,56 & 0,0349 & 2,29 & 0,0507 & 1,14 & 221,5 & 5,1 & 221,0 & 5,0 \\
\hline 11CO-66@24 & 2312 & 363 & 0,16 & 0,23 & 0,277 & 2,86 & 0,0377 & 2,71 & 0,0533 & 0,91 & 248,1 & 6,3 & 238,4 & 6,3 \\
\hline 11CO-66@5 & 4261 & 922 & 0,22 & 1,12 & 0,281 & 2,04 & 0,0385 & 1,70 & 0,0528 & 1,13 & 251,1 & 4,6 & 243,7 & 4,1 \\
\hline 11CO-66@20 & 1609 & 411 & 0,26 & 0,75 & 0,330 & 2,34 & 0,0462 & 2,13 & 0,0518 & 0,98 & 289,3 & 5,9 & 291,1 & 6,1 \\
\hline 11Co-66@26 & 2123 & 377 & 0,18 & 1,19 & 0,343 & 1,86 & 0,0466 & 1,51 & 0,0534 & 1,08 & 299,6 & 4,8 & 293,9 & 4,3 \\
\hline 11CO-66@12 & 1561 & 523 & 0,34 & 0,29 & 0,356 & 2,05 & 0,0485 & 1,82 & 0,0533 & 0,94 & 309,6 & 5,5 & 305,3 & 5,4 \\
\hline 11Co-66@21 & 1929 & 330 & 0,17 & 0,21 & 0,365 & 1,69 & 0,0498 & 1,52 & 0,0531 & 0,75 & 316,1 & 4,6 & 313,5 & 4,6 \\
\hline 11Co-66@7 & 1756 & 400 & 0,23 & 0,10 & 0,379 & 1,70 & 0,0518 & 1,50 & 0,0530 & 0,81 & 326,1 & 4,8 & 325,6 & 4,8 \\
\hline 11CO-66@10 & 2873 & 326 & 0,11 & 0,03 & 0,388 & 1,61 & 0,0531 & 1,54 & 0,0530 & 0,49 & 332,8 & 4,6 & 333,5 & 5,0 \\
\hline 11CO-66@16 & 1554 & 454 & 0,29 & 0,01 & 0,392 & 1,80 & 0,0534 & 1,52 & 0,0532 & 0,97 & 335,6 & 5,2 & 335,6 & 5,0 \\
\hline 11CO-66@22 & 1392 & 445 & 0,32 & 0,06 & 0,396 & 1,69 & 0,0539 & 1,50 & 0,0532 & 0,78 & \#NOM? & 4,9 & 338,6 & 5,0 \\
\hline Qinghu@1 & 1070 & 589 & 0,55 & 0,02 & 0,16713 & 2,31 & 0,0250 & 1,54 & 0,04858 & 1,72 & 156,9 & 3,4 & 158,9 & 2,4 \\
\hline Qinghu@2 & 1344 & 779 & 0,58 & 0,08 & 0,16593 & 2,10 & 0,0252 & 1,52 & 0,04771 & 1,44 & 155,9 & 3,0 & 160,6 & 2,4 \\
\hline Qinghu@3 & 1263 & 598 & 0,47 & 0,03 & 0,17289 & 2,09 & 0,0248 & 1,51 & 0,05058 & 1,44 & 161,9 & 3,1 & 157,9 & 2,4 \\
\hline Qinghu@4 & 888 & 392 & 0,44 & 0,05 & 0,16895 & 2,86 & 0,0250 & 1,51 & 0,04892 & 2,43 & 158,5 & 4,2 & 159,5 & 2,4 \\
\hline Qinghu@5 & 1491 & 754 & 0,51 & 0,02 & 0,17206 & 2,33 & 0,0255 & 1,51 & 0,04893 & 1,78 & 161,2 & 3,5 & 162,4 & 2,4 \\
\hline Qinghu@6 & 954 & 357 & 0,37 & 0,13 & 0,16888 & 2,49 & 0,0249 & 1,51 & 0,04921 & 1,98 & 158,4 & 3,7 & 158,5 & 2,4 \\
\hline Qinghu@7 & 1380 & 531 & 0,38 & 0,16 & 0,16913 & 3,02 & 0,0251 & 1,50 & 0,04881 & 2,62 & 158,7 & 4,4 & 160,0 & 2,4 \\
\hline Qinghu@8 & 2383 & 457 & 0,19 & 0,06 & 0,17303 & 2,13 & 0,0256 & 1,50 & 0,04901 & 1,50 & 162,0 & 3,2 & 163,0 & 2,4 \\
\hline Qinghu@9 & 1788 & 640 & 0,36 & 0,05 & 0,17086 & 1,94 & 0,0252 & 1,51 & 0,04925 & 1,21 & 160,2 & 2,9 & 160,2 & 2,4 \\
\hline Qinghu@10 & 804 & 334 & 0,42 & 0,10 & 0,16755 & 2,83 & 0,0254 & 1,52 & 0,04779 & 2,38 & 157,3 & 4,1 & 161,9 & 2,4 \\
\hline Qinghu@11 & 945 & 409 & 0,43 & 0,01 & 0,17164 & 2,46 & 0,0249 & 1,50 & 0,05001 & 1,94 & 160,8 & 3,7 & 158,5 & 2,4 \\
\hline Qinghu@12 & 703 & 300 & 0,43 & 0,07 & 0,16540 & 2,09 & 0,0249 & 1,50 & 0,04816 & 1,46 & 155,4 & 3,0 & 158,6 & 2,4 \\
\hline Qinghu@13 & 1301 & 551 & 0,42 & 0,01 & 0,17123 & 1,78 & 0,0250 & 1,50 & 0,04958 & 0,96 & 160,5 & 2,7 & 159,5 & 2,4 \\
\hline Qinghu@14 & 633 & 227 & 0,36 & 0,00 & 0,16944 & 2,06 & 0,0251 & 1,51 & 0,04897 & 1,40 & 158,9 & 3,0 & 159,8 & 2,4 \\
\hline Qinghu@15 & 2014 & 557 & 0,28 & 0,01 & 0,17387 & 1,78 & 0,0251 & 1,50 & 0,05019 & 0,95 & 162,8 & 2,7 & 159,9 & 2,4 \\
\hline Qinghu@16 & 1209 & 554 & 0,46 & 0,00 & 0,17026 & 1,80 & 0,0252 & 1,50 & 0,04905 & 1,00 & 159,6 & 2,7 & 160,3 & 2,4 \\
\hline Qinghu@17 & 1362 & 797 & 0,59 & 0,11 & 0,17376 & 1,93 & 0,0253 & 1,50 & 0,04986 & 1,21 & 162,7 & 2,9 & 160,9 & 2,4 \\
\hline Qinghu@18 & 980 & 440 & 0,45 & 0,10 & 0,17369 & 1,94 & 0,0253 & 1,50 & 0,04977 & 1,23 & 162,6 & 2,9 & 161,1 & 2,4 \\
\hline Qinghu@19 & 980 & 440 & 0,45 & 0,10 & 0,17369 & 1,94 & 0,0253 & 1,50 & 0,04977 & 1,23 & 162,6 & 2,9 & 161,1 & 2,4 \\
\hline Qinghu@20 & 1552 & 930 & 0,60 & 0,04 & 0,17328 & 1,80 & 0,0253 & 1,55 & 0,04959 & 0,92 & 162,3 & 2,7 & 161,3 & 2,5 \\
\hline Qinghu@21 & 1144 & 478 & 0,42 & 0,08 & 0,16905 & 1,99 & 0,0256 & 1,50 & 0,04797 & 1,30 & 158,6 & 2,9 & 162,7 & 2,4 \\
\hline Qinghu@22 & 2559 & 1041 & 0,41 & 0,01 & 0,17369 & 1,66 & 0,0256 & 1,50 & 0,04913 & 0,70 & 162,6 & 2,5 & 163,2 & 2,4 \\
\hline
\end{tabular}

